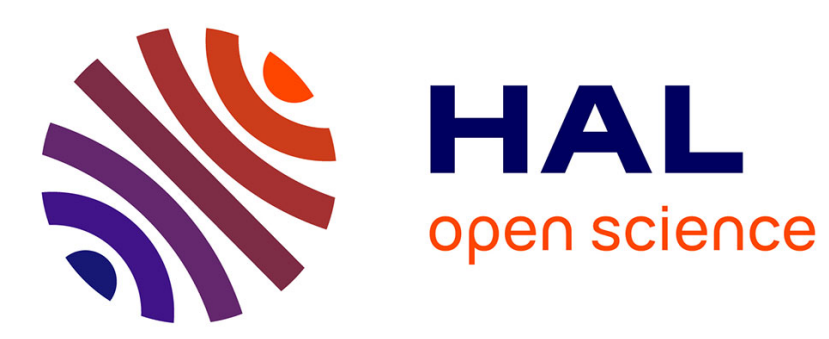

\title{
Atomic layer deposition for biosensing applications
}

Octavio Graniel, Matthieu Weber, Sebastien Balme, Philippe Miele, Mikhael Bechelany

\section{To cite this version:}

Octavio Graniel, Matthieu Weber, Sebastien Balme, Philippe Miele, Mikhael Bechelany. Atomic layer deposition for biosensing applications. Biosensors and Bioelectronics, 2018, 122, pp.147 - 159. 10.1016/j.bios.2018.09.038 . hal-01919095

\section{HAL Id: hal-01919095 \\ https://hal.umontpellier.fr/hal-01919095}

Submitted on 4 Jun 2021

HAL is a multi-disciplinary open access archive for the deposit and dissemination of scientific research documents, whether they are published or not. The documents may come from teaching and research institutions in France or abroad, or from public or private research centers.
L'archive ouverte pluridisciplinaire HAL, est destinée au dépôt et à la diffusion de documents scientifiques de niveau recherche, publiés ou non, émanant des établissements d'enseignement et de recherche français ou étrangers, des laboratoires publics ou privés. 


\title{
Atomic Layer Deposition for Biosensing Applications
}

\author{
Octavio Graniel ${ }^{1}$, Matthieu Weber ${ }^{1}$, Sébastien Balme ${ }^{1}$, Philippe Miele ${ }^{1,2}$ and Mikhael Bechelany ${ }^{* 1}$ \\ ${ }^{1}$ Institut Européen des Membranes IEM, UMR-5635, Université de Montpellier, ENSCM, CNRS, Place \\ Eugène Bataillon, F-34095 Montpellier Cedex 5, France \\ 2Institut Universitaire de France (IUF), MESRI, 1 rue Descartes, 75231 Paris cedex 05, France \\ * Corresponding author: mikhael.bechelany@umontpellier.fr
}

\begin{abstract}
Atomic layer deposition (ALD) is a thin film deposition technique currently used in various nanofabrication processes for microelectronic applications. The ability to coat high aspect ratio structures with a wide range of materials, the excellent conformality, and the exquisite thickness control have made ALD an essential tool for the fabrication of many devices, including biosensors. This mini-review aims to provide a summary of the different ways ALD has been used to prepare biosensor devices. The materials that have been deposited by ALD, the use of the ALD layers prepared and the different types of biosensors fabricated are presented. A selected list of studies will be used to illustrate how the ALD route can be implemented to improve the operational performance of biosensors. This work comprehensively shows the benefits of ALD and its application in various facets of biosensing and will help in exploiting the numerous prospects of this emerging and growing field.
\end{abstract}

\section{Introduction}

Atomic layer deposition (ALD) is a vapor deposition technique enabling the preparation of thin film materials with high conformality and excellent control over the thickness (Chalker, 2016; George and Steven M. George, 2010; Ritala and Leskelä, 2002). Its origins can be traced back to two different places (Puurunen, 2014). ALD was first developed by Aleskovskii during the 1960s in Russia and was referred to as molecular layering (ML) (Malygin et al., 2015). Later on, at the beginning of the 1970s in Finland, Suntola developed the atomic layer epitaxy (ALE) technique to deposit ZnS for electroluminescent displays (Puurunen, 2014; Suntola and Antson, 1977). In the next decades and up to today, the route was then referred to as ALD.

ALD is based on self-limiting reactions between two gaseous precursors and allows the deposition of thin films in a layer-by-layer fashion. The ability to deposit conformal films on high aspect ratio structures, with high uniformity over large areas, at (relatively) low temperatures, has made ALD a technique of choice for the preparation of ultrathin films and a key enabling technology (George and Steven M. George, 2010; Leskelä and Ritala, 2003; Ritala and Leskelä, 2002). ALD allows the deposition of a wide range of materials such as oxides (George and Steven M. George, 2010; Hämäläinen et al., 2014), nitrides (Kim, 2003; Weber et al., 2017), sulfides (Meng et al., 2017; Peters et al., 2015), and pure elements (Aaltonen et al., 2004; Johnson et al., 2014; Lim et al., 2003; Weber et al., 2014). These features 
have made ALD a relevant technique for many applications such as fuel cells (Gong et al., 2013), metal oxide semiconductor field effect transistors (MOSFETs) (Hong et al., 2016), water splitting (Ho et al., 2018) and purification (Weber et al., 2018), encapsulation (Black et al., 2018), membranes (Weber et al., 2017), solar cells (Elias et al., 2012; Van Delft et al., 2012), and batteries (Liu et al., 2014). Also, the possibility of controlling the composition of the deposited layer by making nanolaminate or alloyed structures allows the tailoring of the chemical and physical properties of the ALD prepared materials (Chaaya et al., 2014; Gu et al., 2013).

ALD is a cycle based process involving four steps (depicted schematically in Figure 1). In the first step, a precursor is introduced into the reactor chamber and is left enough time to react with the surface groups of the substrate. Next, the unreacted precursor molecules and the by-products are removed by purging/pumping the system with an inert gas (usually $\mathrm{N}_{2}$ or Ar). The third step involves the introduction of a second precursor (the co-reactant) to react with the adsorbed molecules. The final step consists in purging/pumping again the system to remove unreacted precursor and by-products molecules. As a result, one (sub) monolayer of the desired material is deposited on the substrate surface. This cycle is then repeated until the desired thickness is obtained.

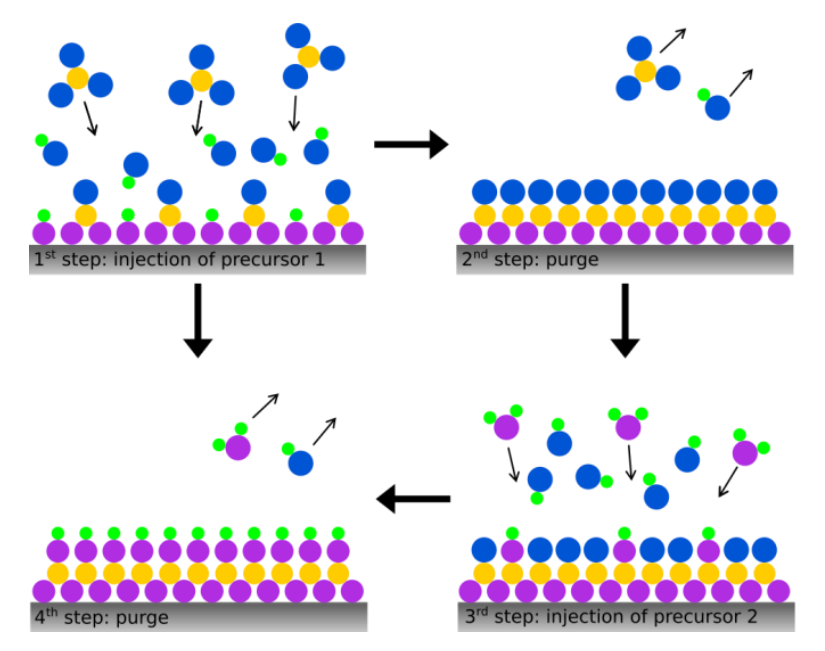

Figure 1. Schematic representation of the ALD process

The use of ALD in the fabrication of nanomaterials for biological and medical applications has proliferated and is now widely spread (Guo et al., 2010; Marichy et al., 2012; Pessoa et al., 2017; VähäNissi et al., 2014; K. Zhang et al., 2017). The compatibility of ALD with the nanoscale of the components found in biomedical devices, the biocompatibility of the materials that can be deposited, and the tuning of the chemical reactivity are some of the reasons why there is a keen interest for using ALD for biomedical applications. Among these applications, biosensing has recently benefited from ALD as a tool for the fabrication of biosensors. Figure 2 shows a histogram of the number of publications (using the Web of Science platform) referring to "biosens" and either "atomic layer deposition" or "ALD". The survey clearly shows that the number of works relating both terms has been steadily increasing in the last decade. 


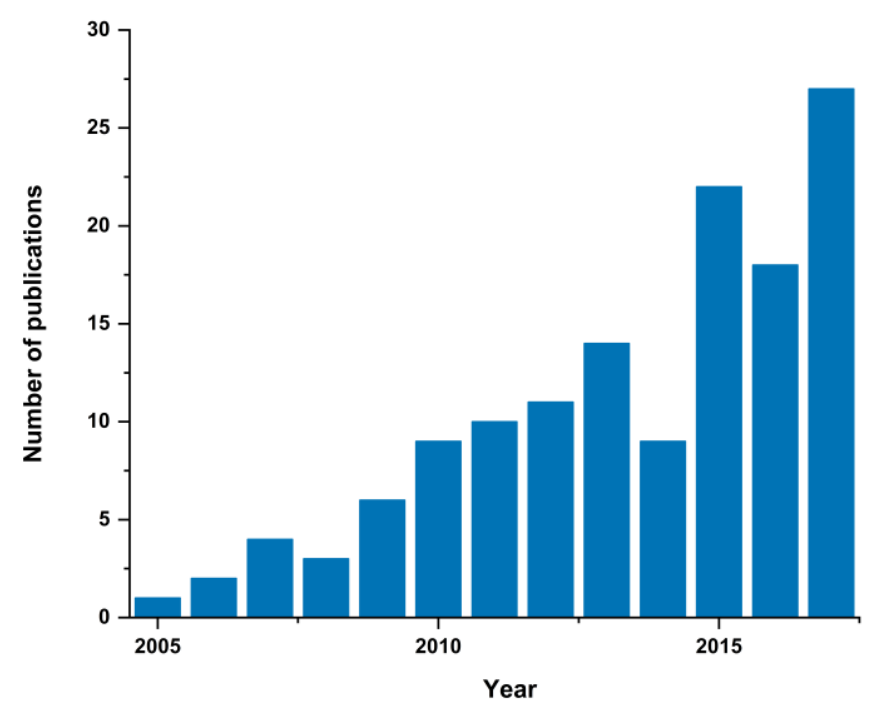

Figure 2. Histogram showing the number of publications referring to "biosens" and either "atomic layer deposition" or "ALD" using the Web of Science platform.

Generally speaking, biosensors are devices that allow the selective detection of a target molecule (Turner, 2013), making them useful for many applications such as clinical diagnosis (Fu et al., 2016), food safety (Luo et al., 2009), environmental monitoring (Mishra et al., 2017), security and bioterrorism (Liu et al., 2018; Muhammad-Tahir and Alocilja, 2003). A typical biosensor configuration is presented in Figure 3. Biosensors have two main components: a biorecognition layer and a physical transducer. When the analyte of interest (e.g., low molecular compound, (bio) macromolecules, protein, virus, cell) is captured by the biorecognition element, a biochemical signal is produced, and the transducer element transforms it into a signal that can be measured and correlated (in some cases) to the concentration of it. Biosensors are selective thanks to the bioselective layer that interacts only with the analyte of interest. They can be classified either by the type of biorecognition element (e.g., enzyme, antibodies, cell, nucleic acids) or by the nature of transducer signal (i.e., electrochemical, optical, electrical, mass-sensitive, magnetic). 


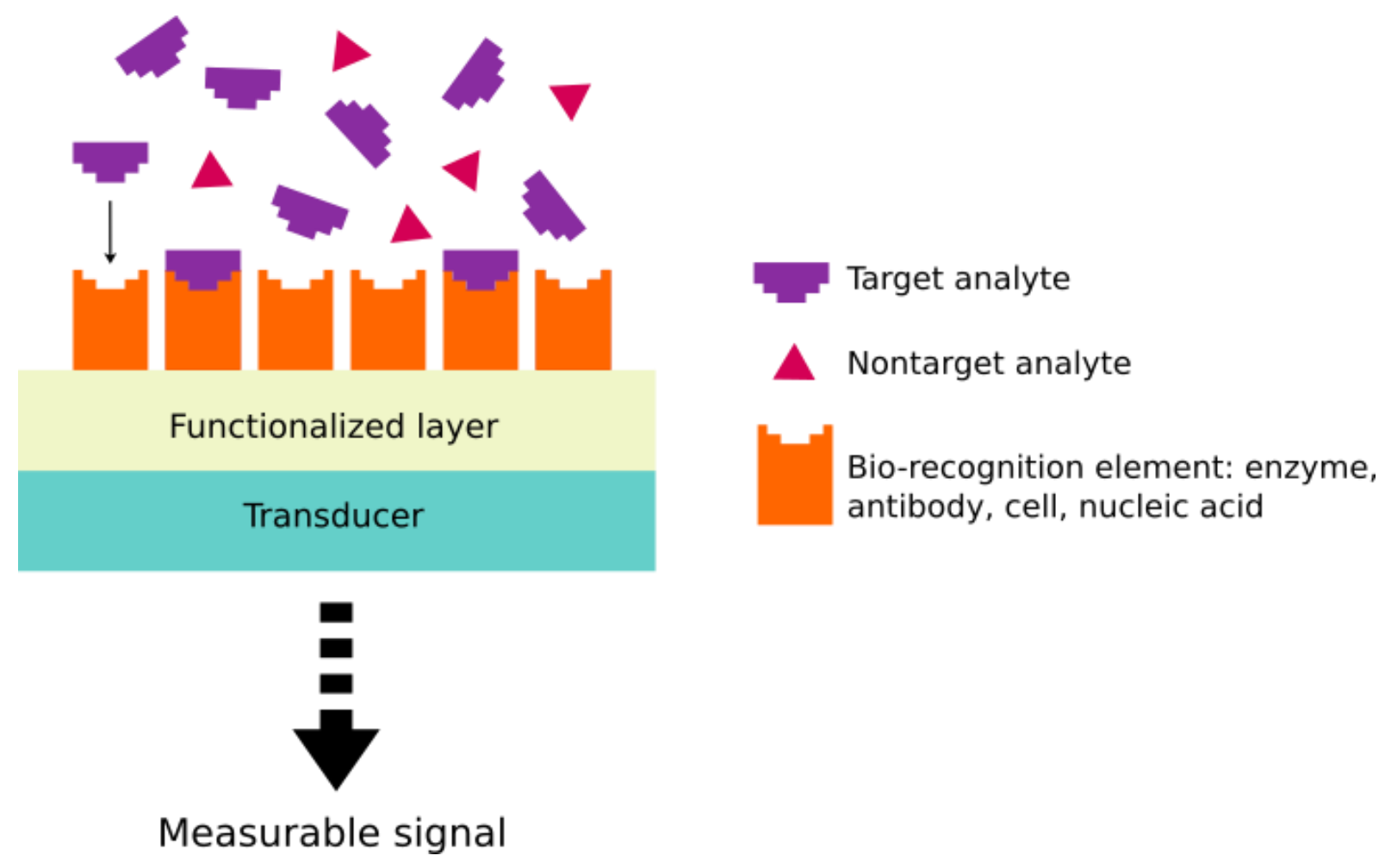

Figure 3. Typical biosensor configuration

In the field of biosensing, ALD has been used mainly as a fabrication tool, or as a way to enhance the biosensing performance. In the next sections, a review of the different applications of ALD for these purposes is given. The type of materials deposited by ALD, the use of the ALD layers prepared, the different types of biosensors fabricated, and the detection methods used for sensing are reported.

\section{ALD for biosensing applications}

ALD has proven to be a versatile technique to fabricate nanostructures (Hong and Kim, 2016; Li et al., 2017; Viter et al., 2015; Xiong et al., 2015). The precise thickness control and excellent conformality allowed by the technique enables to fabricate complex nanostructures with a high surface area that can be used for the design of biosensors. Some of the films deposited by ALD can function as sacrificial layers that can be removed later by chemical or physical etching to produce the desired nanostructure. Other films can be used to fabricate the transducer element of a biosensor, which requires biocompatible materials that can interact with the bio-recognition elements. Additionally, they can be used to protect biosensors and improve their stability towards harsh environments. In this section, ALD films deposited by ALD used in combination with other techniques for nanofabrication will be discussed.

\subsection{ALD to produce nanostructured biosensors}


Recently, the interest in fabricating biosensors with nano-sized features has grown because their dimensions are in the same range as the biological components of the bio-recognition layer. A selection of nanostructured biosensors fabricated using ALD is presented in Table 1.

Table 1. Examples of films deposited by ALD for the fabrication of nanostructured biosensors

\begin{tabular}{|c|c|c|c|c|c|c|}
\hline $\begin{array}{l}\text { Material } \\
\text { deposited } \\
\text { by ALD }\end{array}$ & $\begin{array}{l}\text { Application } \\
\text { of the ALD } \\
\text { coating }\end{array}$ & Substrate/Probe & Analyte & $\begin{array}{l}\text { Detection } \\
\text { Method }\end{array}$ & $\begin{array}{l}\text { Concentration } \\
\text { range/Detection Limit }\end{array}$ & Ref. \\
\hline $\mathrm{Al}_{2} \mathrm{O}_{3}$ & $\begin{array}{l}\text { Sacrificial } \\
\text { layer for } \\
\text { nanogap } \\
\text { fabrication }\end{array}$ & $\begin{array}{l}\text { Gold } \\
\text { nanogap/Biotin }\end{array}$ & Streptavidin & $\begin{array}{l}\text { Electrochemical } \\
\text { (current) }\end{array}$ & $\begin{array}{l}\text { Detection down to } 1.5 \\
\mathrm{nM}\end{array}$ & $\begin{array}{l}\text { (Jan } \\
\text { g et } \\
\text { al., } \\
200 \\
7)\end{array}$ \\
\hline $\mathrm{Al}_{2} \mathrm{O}_{3}$ & $\begin{array}{l}\text { Layer for } \\
\text { nanoring } \\
\text { fabrication }\end{array}$ & $\begin{array}{l}\text { Plasmonic } \\
\text { nanoring cavities }\end{array}$ & Adenine & $\begin{array}{l}\text { Optical (surface } \\
\text { enhanced } \\
\text { Raman } \\
\text { spectroscopy } \\
\text { [SERS]) }\end{array}$ & $\begin{array}{l}\text { Limit of detection } 76 \\
\mathrm{nM}\end{array}$ & $\begin{array}{l}(\mathrm{Im} \\
\text { et } \\
\text { al., } \\
201 \\
3)\end{array}$ \\
\hline $\mathrm{Al}_{2} \mathrm{O}_{3}$ & $\begin{array}{l}\text { Layer for } \\
\text { coax } \\
\text { fabrication }\end{array}$ & $\begin{array}{l}\text { Nanoscale coaxial } \\
\text { electrodes/anti- } \\
\text { cholera toxin } \\
\text { antibody }\end{array}$ & $\begin{array}{l}\text { Cholera } \\
\text { toxin }\end{array}$ & $\begin{array}{l}\text { Electrochemical } \\
\text { (DPV } \\
\text { [differential } \\
\text { pulse } \\
\text { voltammetry] or } \\
\text { SWV [square } \\
\text { wave } \\
\text { voltammetry]) }\end{array}$ & $\begin{array}{l}\text { Linear dynamic range } \\
\text { of detection of } 10 \\
\mathrm{ng} / \mathrm{ml}-1 \mu \mathrm{g} / \mathrm{ml} \\
\text { Limit of detection } 2 \\
\mathrm{ng} / \mathrm{ml}\end{array}$ & $\begin{array}{l}\text { (Ar } \\
\text { chi } \\
\text { bal } \\
\text { d et } \\
\text { al., } \\
201 \\
5)\end{array}$ \\
\hline $\mathrm{Al}_{2} \mathrm{O}_{3}$ & $\begin{array}{l}\text { Nano- } \\
\text { spacer for } \\
\text { metal- } \\
\text { enhanced } \\
\text { fluorescence } \\
\text { (MEF) }\end{array}$ & $\begin{array}{l}\text { Microarray } \\
\text { platform on Ag } \\
\text { film/split DNA } \\
\text { aptamer }\end{array}$ & $\begin{array}{l}17-\beta- \\
\text { estradiol }\end{array}$ & $\begin{array}{l}\text { Optical } \\
\text { (fluorescence) }\end{array}$ & $\begin{array}{l}\text { Detection limit of } 1 \\
\mathrm{pg} / \mathrm{ml}\end{array}$ & $\begin{array}{l}\text { (Le } \\
\text { e et } \\
\text { al., } \\
201 \\
7)\end{array}$ \\
\hline $\mathrm{Al}_{2} \mathrm{O}_{3} / \mathrm{ZnO}$ & $\begin{array}{l}\text { Nanopore } \\
\text { size } \\
\text { modificatio } \\
n, \\
\text { enhancemen } \\
\text { t of sensing } \\
\text { capabilities }\end{array}$ & $\begin{array}{l}\text { poly(ethylene } \\
\text { terephthalate) } \\
(\mathrm{PET}) \\
\text { nanochannel/Al } 2 \\
\mathrm{O}_{3} / \mathrm{ZnO} / \text { biotin }\end{array}$ & $\begin{array}{l}\text { Avidin/stre } \\
\text { ptavidin/bo } \\
\text { vine serum } \\
\text { albumin } \\
\text { (BSA)/IgG } \\
\text { (Immunogl } \\
\text { obulin G) } \\
\text { /anti-BSA }\end{array}$ & $\begin{array}{l}\text { Electrochemical } \\
\text { (current) }\end{array}$ & $\begin{array}{l}\text { Avidin and } \\
\text { streptavidin } \\
\text { discrimination/BSA, } \\
\text { IgG and anti-BSA } \\
\text { detection }\end{array}$ & $\begin{array}{l}\text { (Le } \\
\text { poi } \\
\text { tevi } \\
\text { n et } \\
\text { al., } \\
201 \\
6)\end{array}$ \\
\hline $\mathrm{ZnO}$ & $\begin{array}{l}\text { Decoration } \\
\text { of silicon } \\
\text { nanowires } \\
\text { (SiNWs) } \\
\text { with } \mathrm{ZnO} \\
\text { nanoparticle } \\
\text { s }\end{array}$ & $\begin{array}{l}\text { SiNWs FETs } \\
\text { (field effect } \\
\text { transistor)/chemic } \\
\text { al receptors }\end{array}$ & $\begin{array}{l}\text { Explosive } \\
\text { chemical } \\
\text { species }\end{array}$ & $\begin{array}{l}\text { Electrochemical } \\
\text { (FET) }\end{array}$ & $\begin{array}{l}\text { Detection down to } \\
\text { the parts-per- } \\
\text { quadrillion range }\end{array}$ & $\begin{array}{l}\text { (Lic } \\
\text { hte } \\
\text { nst } \\
\text { ein } \\
\text { et } \\
\text { al., } \\
201 \\
4)\end{array}$ \\
\hline $\mathrm{ZnO}$ & $\begin{array}{l}\text { Electrode } \\
\text { body }\end{array}$ & $\begin{array}{l}\mathrm{ZnO} / \mathrm{ZnS} \\
\text { core/shell } \\
\text { nanotubes/GOx } \\
\text { (glucose oxidase) }\end{array}$ & Glucose & $\begin{array}{l}\text { Electrochemical } \\
\text { (current) }\end{array}$ & $\begin{array}{l}\text { Linear range of } 2.39 \times \\
10^{-5}-2.66 \times 10^{-4} \mathrm{mM}\end{array}$ & $\begin{array}{l}\text { Ta } \\
\text { rish } \\
\text { et } \\
\text { al., } \\
201 \\
7)\end{array}$ \\
\hline
\end{tabular}


Jang et al. deposited a film of $\mathrm{Al}_{2} \mathrm{O}_{3}$ by $\mathrm{ALD}$ to be used as a sacrificial layer for the fabrication of a vertical nanogap in a label-free electrical biosensor for the detection of streptavidin (Jang et al., 2007). $\mathrm{Al}_{2} \mathrm{O}_{3}$ films of 5, 10 and $15 \mathrm{~nm}$ were deposited to explore the effect on sensitivity from different gap sizes. Figure 4 shows the vertical nanogap fabricated with $5 \mathrm{~nm}$ of $\mathrm{Al}_{2} \mathrm{O}_{3}$ and $2 \mathrm{~nm}$ of Ti. By comparing the ratio of the current before and after binding of streptavidin to biotin, they found out that the $7 \mathrm{~nm}$ gap is too small for the binding to take place (no change in current). However, they observed significant current increases for the 12 and $17 \mathrm{~nm}$ gaps.

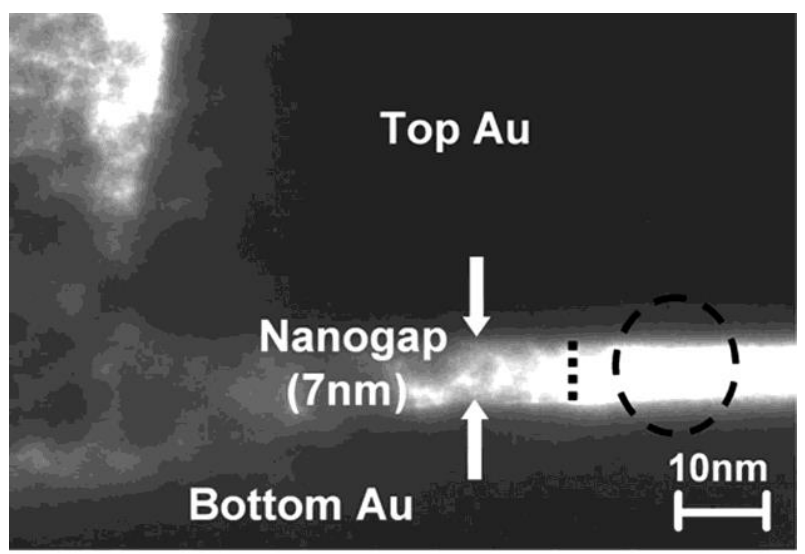

(a)

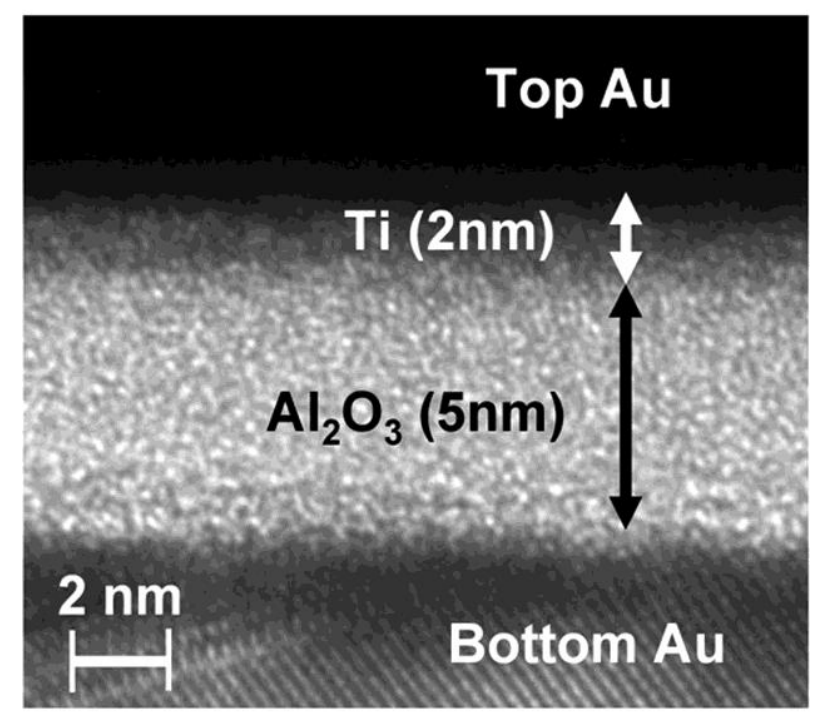

(b)

Figure 4. (a) Cross-sectional transmission electron microscopy (TEM) images of a $7 \mathrm{~nm}$ vertical gold nanogap. Vertical line is an interfacial boundary of $\mathrm{Al}_{2} \mathrm{O}_{3}$ and air, which is filled with Pt for TEM analysis and (b) close-up view of circle in (a). Reprinted with permission from (Jang et al., 2007). Copyright 2007 American Vacuum Society.

Similarly, Im et al. combined nanosphere lithography (NSL) and ALD for the fabrication of a periodic array of ring-shaped nanocavities with $10 \mathrm{~nm}$ gap size to be used as a SERS substrate (Im et al., 2013). Figure 5 presents a schematic representation of the fabrication process. The number of ALD cycles controls the thickness of the $\mathrm{Al}_{2} \mathrm{O}_{3}$ layer and this, in turn, controls the resulting gap size. Adenine was 
used as an analyte to test the film-over-nanospheres (FON) substrate "FON-gap." SERS measurements revealed a strong $731 \mathrm{~cm}^{-1}$ purine stretch coming from adenine that was used to test the detection limits of the SERS substrate. A $76 \mathrm{nM}$ detection limit was obtained, which makes the FON-gap an excellent bioanalytical platform for SERS biosensing.

a
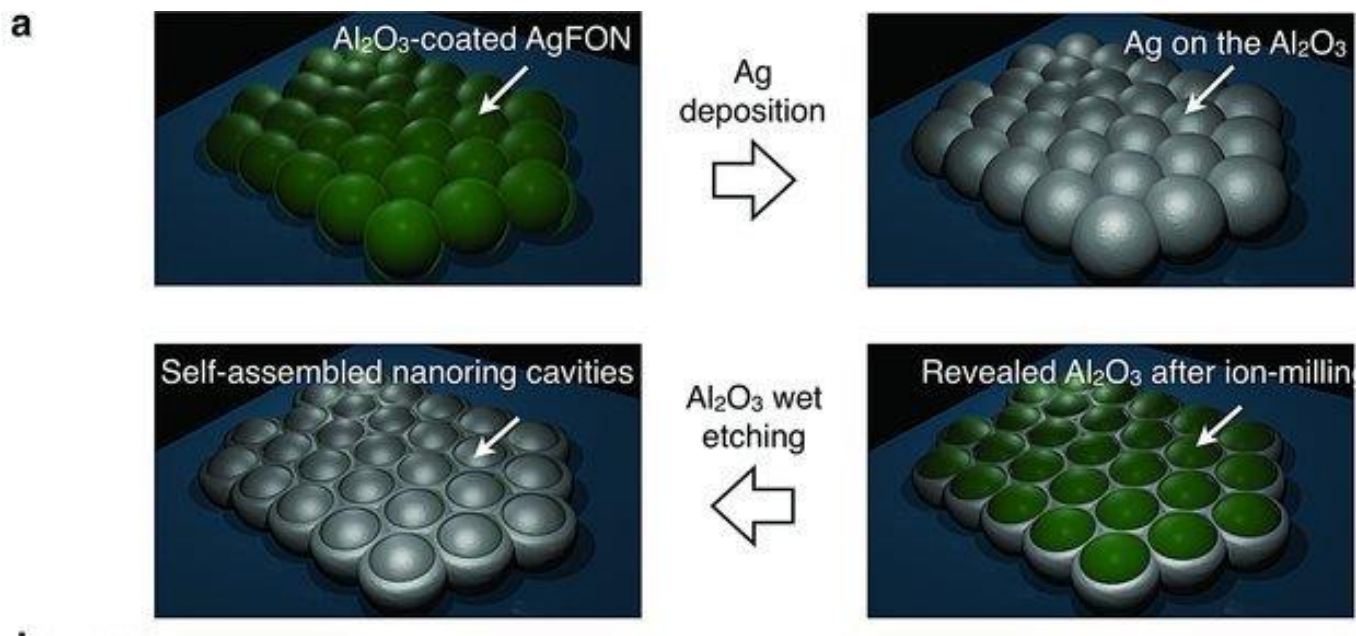

Anisotropic

etching

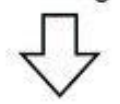

b
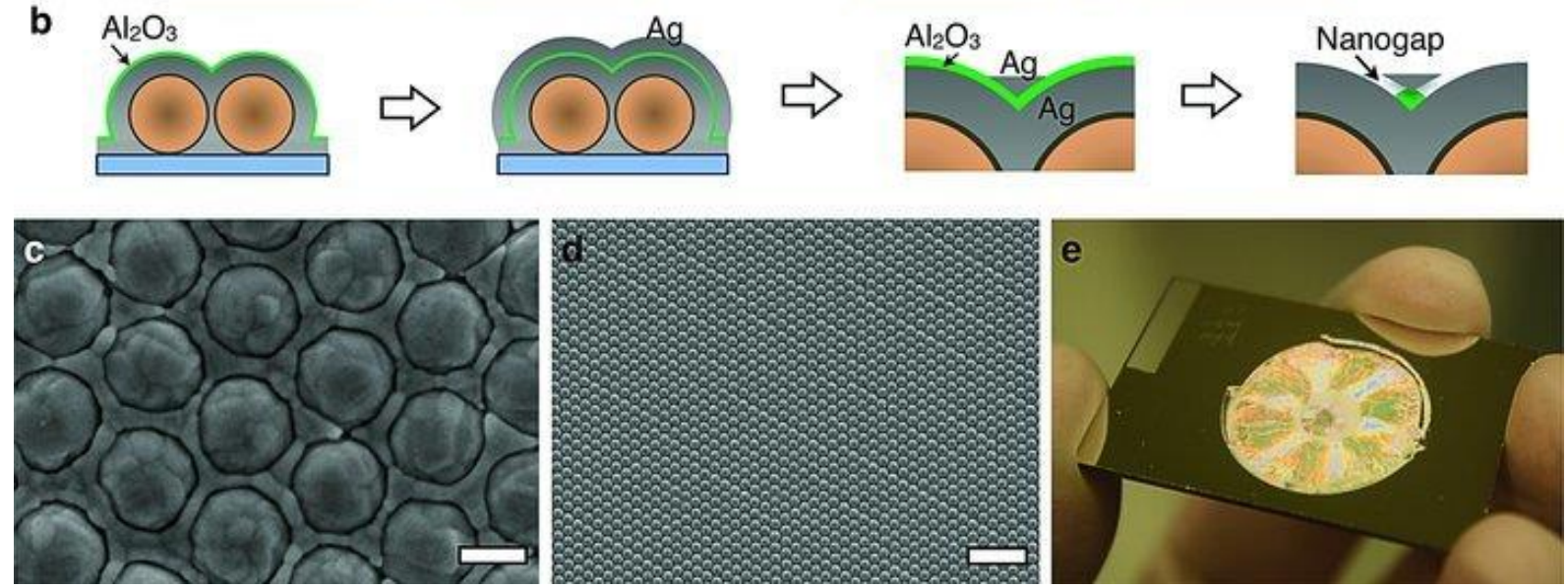

Figure 5. (a) A schematic representation of the fabrication process for plasmonic nanoring cavities based biosensors, using NSL and ALD. First ALD is used to conformally deposit an $\mathrm{Al}_{2} \mathrm{O}_{3}$ layer on the FON substrate prepared by depositing $\mathrm{Ag}$ films on polystyrene nanospheres dispersed on a glass slide. Another $\mathrm{Ag}$ layer is then deposited on the $\mathrm{Al}_{2} \mathrm{O}_{3}$ layer, forming $\mathrm{Ag} / \mathrm{Al}_{2} \mathrm{O}_{3} / \mathrm{Ag}$ layers stacked on the nanospheres. Anisotropic etching of the top Ag layer using ion-milling reveals the underlying $\mathrm{Al}_{2} \mathrm{O}_{3}$ layer with a bowl-shaped $\mathrm{Ag}$ residual layer on the nanospheres. Partially removing the $\mathrm{Al}_{2} \mathrm{O}_{3}$ layer reveals $\mathrm{Ag} / \mathrm{air} / \mathrm{Ag}$ nanoring cavities with a nanogap size defined by the thickness of the ALD-grown $\mathrm{Al}_{2} \mathrm{O}_{3}$ film. (b) Cross-sectional schematics of the fabrication process. (c) Scanning electron micrograph (SEM) of the nanoring cavities on the FON substrates. Scale bar: $200 \mathrm{~nm}$. (d) SEM image of the nanoring cavity array formed over a $16 \mu \mathrm{m} \times 10 \mu \mathrm{m}$ area. (e) Photograph of the nanoring cavity (FONgap) sample. On the standard glass slide, the FON-gap structures are made in a $2 \mathrm{~cm}$-wide circular area. Reprinted with permission from (Im et al., 2013). Copyright 2013 John Wiley and Sons.

In order to fabricate materials with low dimensions, ALD has been used to fill high aspect ratio nanoholes of porous materials (Elam et al., 2006) such as anodic aluminum oxide (AAO) (Banerjee et al., 2009; Yao et al., 2015). Thanks to its controllable pore diameter, periodicity, and density distribution (Poinern et al., 2011), AAO has been incorporated successfully as a template for 
biosensors fabrication. As an example, Tarish et al. obtained highly ordered $\mathrm{ZnO} / \mathrm{ZnS}$ core/shell nanotube arrays by using ALD of $\mathrm{ZnO}$ and rapid thermal deposition with $\mathrm{AAO}$ as a template (Tarish et al., 2017).

ALD has also been used as a tool for tuning single solid-state nanopore sensors. Such sensors, inspired by the pioneering work of Kasianowicz et al. on $\alpha$-hemolysin (Kasianowicz et al., 1996)], are nanometer-sized apertures fabricated in thin films that allow label-free detection of single molecules (Dekker, 2007; Lepoitevin et al., 2017; Miles et al., 2013). Thanks to its conformal deposition, ALD has been able to coat nanopores with high aspect ratio (Spende et al., 2015). For example, Cabello-Aguilar et al. deposited $\mathrm{Al}_{2} \mathrm{O}_{3} / \mathrm{ZnO}$ nanolaminates to reduce the size of a hydrophobic nanopore (CabelloAguilar et al., 2013). The diameter of the nanopore was fine-tuned for $\alpha$-hemolysin insertions. $\mathrm{Al}_{2} \mathrm{O}_{3} / \mathrm{ZnO}$ nanolaminates were chosen due to their low surface roughness, which prevents the collonar growth of layers that can clog the nanopore (Balme et al., 2015). The ability of ALD to homogenously coat the internal surface of a nanopore allows an excellent surface functionalization (Lepoitevin et al., 2015). This capability limits the non-controlled adsorption of proteins outside the track-etched nanopore and is useful for biosensing (Lepoitevin et al., 2016). ALD has also been used to reduce electrical noise in SiN (Chen et al., 2004) and PET (Thangaraj et al., 2016) nanopores by coating them with a thin layer of $\mathrm{Al}_{2} \mathrm{O}_{3}$.

These examples show the relevance of ALD for the fabrication of nanostructured biosensors and its versatility to be used in combination with other fabrication techniques. The advantages of using ALD to deposit thin films can be seen in the nanometer scale features achieved in the different types of biosensors and the various morphologies that can be coated.

\subsection{ALD for the fabrication of transducers}

In order to produce a signal that can be measured and correlated to the presence and concentration (in some cases) of a specific analyte, the transducer element of a biosensor requires well-defined morphologies with optimal optical, electrical, chemical, mechanical, and structural properties (Tereshchenko et al., 2016; Velasco-Garcia and Mottram, 2003; Zhang et al., 2000). It is crucial that the interaction between the analyte and the biorecognition element on the transducer material produces a change in one or more of its physicochemical properties (e.g., mass change, photoluminescence change, $\mathrm{pH}$ change, photocurrent change). Also, the biocompatibility of the transducer element is necessary to facilitate the immobilization of the biorecognition elements (Guo et al., 2010; Im et al., 2012; Schindler et al., 2008). The capabilities offered by ALD can effectively meet these challenges and examples of oxide transducers fabricated with ALD are presented in Table 2.

Table 2. Examples of materials deposited by ALD for the fabrication of transducers

\begin{tabular}{|c|c|c|c|c|c|c|}
\hline $\begin{array}{l}\text { Material } \\
\text { deposite } \\
\text { d by } \\
\text { ALD }\end{array}$ & $\begin{array}{l}\text { Applicatio } \\
\mathrm{n} \text { of the } \\
\mathrm{ALD} \\
\text { coating }\end{array}$ & Substrate/Probe & $\begin{array}{l}\text { Analyt } \\
\mathrm{e}\end{array}$ & Detection method & $\begin{array}{l}\text { Concentration } \\
\text { range/Detectio } \\
\mathrm{n} \text { Limit }\end{array}$ & Ref. \\
\hline $\mathrm{TiO}_{x}$ & $\begin{array}{l}\text { Transducer } \\
\text { layer }\end{array}$ & $\begin{array}{l}\text { Long-period } \\
\text { grating } \\
(\mathrm{LPG}) / \mathrm{TiO} / \text { Bioti } \\
\mathrm{n}\end{array}$ & Avidin & $\begin{array}{l}\text { Optical (refractive } \\
\text { index) }\end{array}$ & $\begin{array}{l}\text { Detection of } \\
\text { avidin-biotin } \\
\text { complex }\end{array}$ & $\begin{array}{l}\text { (Dominik et } \\
\text { al., 2017) }\end{array}$ \\
\hline $\mathrm{ZnO}$ & $\begin{array}{l}\text { Transducer } \\
\text { layer }\end{array}$ & $\begin{array}{l}\mathrm{ZnO} \\
\text { nanorods/GOx }\end{array}$ & $\begin{array}{l}\text { Glucos } \\
\mathrm{e}\end{array}$ & $\begin{array}{l}\text { Electrochemical } \\
\text { (current) }\end{array}$ & $\begin{array}{l}\text { Sensitivity of } \\
69.8(\mathrm{nA} / \mu \mathrm{M}-\end{array}$ & $\begin{array}{l}\text { (Kim et al., } \\
\text { 2014) }\end{array}$ \\
\hline
\end{tabular}




\begin{tabular}{|c|c|c|c|c|c|c|}
\hline & & & & & $\left.\mathrm{cm}^{2}\right)$ & \\
\hline $\mathrm{ZnO}$ & $\begin{array}{l}\text { Transducer } \\
\text { layer }\end{array}$ & $\begin{array}{l}\mathrm{ZnO} \text { film/GVA } \\
\text { antibody }\end{array}$ & $\begin{array}{l}\text { GVA } \\
\text { antigen }\end{array}$ & $\begin{array}{l}\text { Optical } \\
\text { (photoluminescence } \\
\text { ) }\end{array}$ & $\begin{array}{l}\text { Sensitivity in } \\
\text { the range from } \\
1 \mathrm{pg} / \mathrm{ml} \text { to } 10 \\
\mathrm{ng} / \mathrm{ml}\end{array}$ & $\begin{array}{l}\text { (Tereshchenk } \\
\text { o et al., 2017) }\end{array}$ \\
\hline
\end{tabular}

Recently, Tereshchenko et al. used a ZnO film deposited by ALD as an optical biosensor platform to detect Grapevine virus A-type (GVA) proteins (GVA-antigens) for the first time (Tereshchenko et al., 2017). ZnO was chosen due to its high isoelectric point ( 9.5), biocompatibility for the immobilization of GVA-antibodies, and ability to change its photoluminescence (PL) emission when interacting with biomolecules. In their work, they deposited a $110 \mathrm{~nm}$ thick $\mathrm{ZnO}$ layer on a $\mathrm{Si}$ substrate at a low deposition temperature of $100{ }^{\circ} \mathrm{C}$. By looking at the PL signal of the biosensor while adding different concentrations of GVA-antigen, they detected the protein with sensitivity in the range from $1 \mathrm{pg} / \mathrm{ml}$ to $10 \mathrm{ng} / \mathrm{ml}$. Kim et al. grew $\mathrm{ZnO}$ nanorods using a hydrothermal method and a seed layer deposited by ALD (Kim et al., 2014). A $20 \mathrm{~nm} \mathrm{ZnO}$ was deposited and used to promote the growth of high aspect ratio $\mathrm{ZnO}$ nanorods in a layer-by-layer fashion. $\mathrm{GO}_{\mathrm{x}}$ was immobilized on the $\mathrm{ZnO}$ nanorods to detect glucose over a range of different concentrations by cyclic voltammetry. The biosensor showed a sensitivity of $69.8 \mathrm{nA} /\left(\mu \mathrm{M} \cdot \mathrm{cm}^{2}\right)$ for the $\mathrm{ZnO}$ nanorods with the highest surface area.

Transducer materials can also be functionalized chemically to immobilize the biorecognition element (Arya et al., 2012; Brétangol et al., 2006). The chemical grafting of biomolecules shows an increase of the surface coverage when compared to physical adsorption and improves the general stability and performance of the biosensor (Gervais et al., 2007). $\mathrm{TiO}_{\mathrm{x}}$ was deposited on a LPG induced in an optical fiber as a transducer for the recognition of biotin-avidin interactions (Dominik et al., 2017). The transducer layer was functionalized with amine groups to form a peptide bond with the carboxyl group of biotin. X-ray photoelectron spectroscopy (XPS) was used to confirm the successful functionalization with APTES as well as biotin on the $\mathrm{TiO}_{x}$ layer. A $13.2 \mathrm{~nm}$ shift in the resonance wavelength was obtained when binding of avidin to biotin took place, proving the biosensor's ability to detect this event. The possibility of fabricating the transducer element in biosensors with ALD has been demonstrated in the examples mentioned above. With the growing need to fabricate biosensors with smaller dimensions, faster response rates, and higher sensitivities, the use of transducers prepared by ALD will become more common and will play a key role in the development of these devices.

\subsection{ALD layers to protect biosensors from their environment}

ALD deposited films have been used as protective coatings, for example, to limit corrosion processes (Díaz et al., 2013; Shan et al., 2008; Standridge et al., 2009). The ability to coat large areas with substantial uniformity and excellent conformality are some of the advantages of ALD over other thin film deposition techniques. Also, ALD provides dense, pinhole-free films with outstanding adhesion properties(Matero et al., 1999). These benefits have made ALD an excellent choice to protect the surface of biosensors from aqueous environments and render them stable and, in some cases, reusable. To illustrate this, a list of biosensors with protective coatings deposited by ALD is presented in Table 3.

Table 3. Examples of films deposited by ALD for biosensor protection purposes

\begin{tabular}{llllll}
\hline Material Application of & Substrate/Probe & Analyte & Detection & Concentration & Ref.
\end{tabular}




\begin{tabular}{|c|c|c|c|c|c|c|}
\hline $\begin{array}{l}\text { deposited } \\
\text { by ALD }\end{array}$ & $\begin{array}{l}\text { the ALD } \\
\text { coating }\end{array}$ & & & Method & $\begin{array}{l}\text { range/Detection } \\
\text { Limit }\end{array}$ & \\
\hline $\mathrm{Al}_{2} \mathrm{O}_{3}$ & $\begin{array}{l}\text { Protection } \\
\text { against } \\
\text { oxidation of } \\
\mathrm{Ag}\end{array}$ & $\begin{array}{l}\text { Silver film-over- } \\
\text { nanosphere } \\
(\mathrm{AgFON})\end{array}$ & $\begin{array}{l}\text { Anthrax } \\
\text { biomarker } \\
\text { CaDPA } \\
\text { (calcium } \\
\text { dipicolinate) }\end{array}$ & Optical (SERS) & $\begin{array}{l}\text { Limit of detection } \\
1.4 \times 10^{3} \text { spores }\end{array}$ & $\begin{array}{l}\text { (Zha } \\
\text { ng } \\
\text { et } \\
\text { al., } \\
2006 \\
\text { ) }\end{array}$ \\
\hline $\mathrm{Al}_{2} \mathrm{O}_{3}$ & $\begin{array}{l}\text { Protection of } \\
\mathrm{ZnO}\end{array}$ & $\begin{array}{l}\mathrm{ZnO} \text { passivated } \\
\text { with } \mathrm{Al}_{2} \mathrm{O}_{3}\end{array}$ & Biofilm & $\begin{array}{l}\text { Mass-sensitive } \\
\text { (surface } \\
\text { acoustic wave } \\
{[\text { SAW] })}\end{array}$ & $\begin{array}{l}\text { Limit of detection } \\
5.3 \mathrm{pg}\end{array}$ & $\begin{array}{l}(\mathrm{Ki} \\
\mathrm{m} \text { et } \\
\text { al., } \\
2012 \\
)\end{array}$ \\
\hline $\mathrm{SiO}_{2}$ & $\begin{array}{l}\text { Protection of } \\
\text { nanolaser } \\
\text { structure }\end{array}$ & $\begin{array}{l}\text { InGaAsP multiple } \\
\text { quantum well } \\
(\mathrm{MQW}) / \text { biotin }\end{array}$ & $\begin{array}{l}\text { Streptavidin } \\
\text { tagged with } \\
\text { phosphor } \\
\text { (SAPE) }\end{array}$ & $\begin{array}{l}\text { Optical (air- } \\
\text { bridge-type } \Gamma \text { - } \\
\text { band-edge } \\
\text { laser (BEL) } \\
\text { lasing } \\
\text { wavelength } \\
\text { shift) }\end{array}$ & $\begin{array}{l}\text { Detection of } \\
\text { streptavidin- } \\
\text { biotin reaction }\end{array}$ & $\begin{array}{l}\text { (Cha } \\
\text { et } \\
\text { al., } \\
2015 \\
\text { ) }\end{array}$ \\
\hline
\end{tabular}

Cha et al. used ALD of $\mathrm{SiO}_{2}$ to protect the surface of a photonic crystal (PC) BEL structure (Cha et al., 2015). These In-P based structures are subject to chemical attack, and their surface is full of defects that can cause rapid carrier annihilation. By depositing a $5 \mathrm{~nm} \mathrm{SiO} 2 \mathrm{film}$, they successfully protected the nanolaser device from harsh chemicals and used it as a layer for biotin functionalization. Figure 6 shows the overall functionalization process schematically. Regions with PC pattern show a stronger fluorescence thanks to their higher surface to volume ratio when compared to planar regions. Also, they detected streptavidin with a figure of merit of $\sim 800$, which showed the high sensibility of the BEL biosensor.

(a)
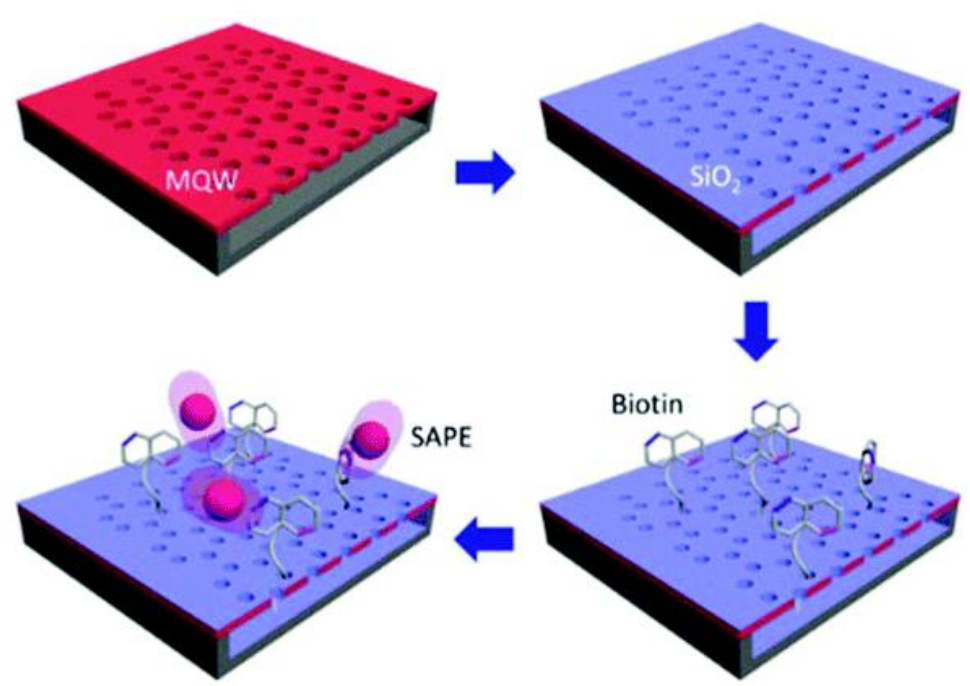

(b)

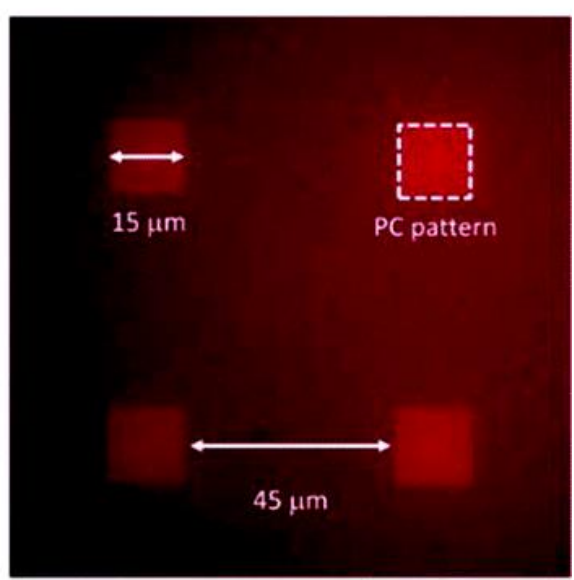

Figure 6. (a) Schematic representation of the surface functionalization steps for biosensing test. From top-left: 2D PC BEL fabrication; conformal deposition of $\mathrm{ALD}-\mathrm{SiO}_{2}$ layer; biotinylation of silicaterminated surface; and chemical interaction between biotin and streptavidin molecules tagged with 
SAPE. (b) Fluorescence microscopy image taken after the dye-conjugated streptavidin was bound onto the biotin-functionalized PC surface. Reprinted with permission from (Cha et al., 2015). Copyright 2015 Royal Society of Chemistry.

The sensitivity of a biosensor can be lowered when a protective layer is applied. The properties of the material to be deposited, as well as its thickness, must be optimized to reduce the possible detrimental effects on the performance of the biosensor. Kim et al. used an $\mathrm{ALD} \mathrm{Al}_{2} \mathrm{O}_{3}$ film as a passivation layer to protect the $\mathrm{ZnO}$ piezoelectric layer from bacterial growth media or animal serum of a SAW biofilm sensor (Kim et al., 2012). They calculated the normalized theoretical sensitivity of the SAW sensor after applying a protective layer of different materials $\left(\mathrm{Al}_{2} \mathrm{O}_{3}, \mathrm{Si}_{3} \mathrm{~N}_{4}, \mathrm{SiO}_{2}\right.$, and Teflon) and observed that $\mathrm{Al}_{2} \mathrm{O}_{3}$ was the one that provided the lowest degradation in sensitivity. A $45 \mathrm{~nm} \mathrm{Al}_{2} \mathrm{O}_{3}$ film was deposited by e-beam evaporation, RF sputtering and ALD to assess the performance of each of the deposition techniques. After two days in Lysogeny Broth (LB) media bacterial suspension, the films prepared by e-beam evaporation and RF sputtering led to some damage and did not protect the $\mathrm{ZnO}$ layer successfully as compared to the ALD film (Figure 7). E. coli was cultured to test the SAW sensor for biofilm growth monitoring, and a detection limit of $5.3 \mathrm{pg}$ was achieved.
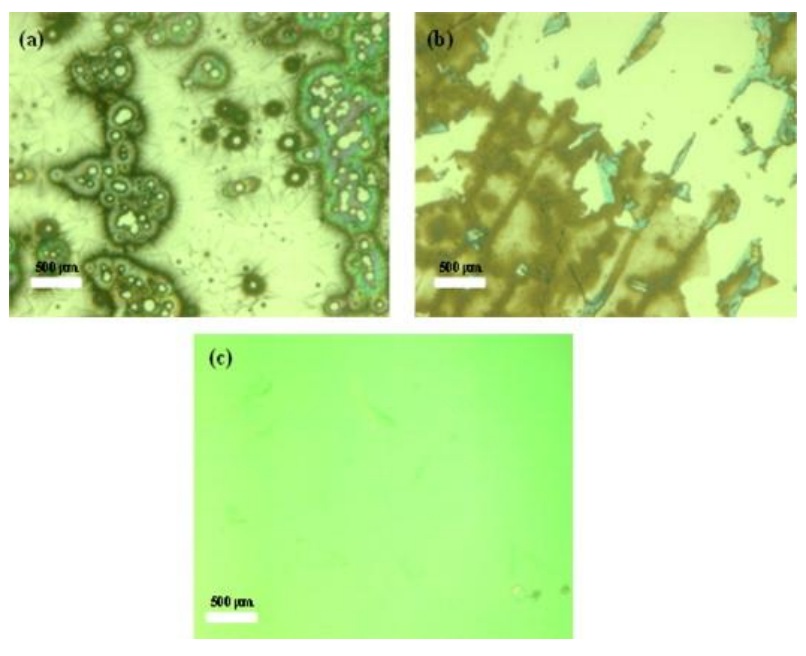

Figure 7. Optical images showing the surface of the SAW sensor passivated with a $45 \mathrm{~nm} \mathrm{Al}_{2} \mathrm{O}_{3}$ film using (a) e-beam evaporation, (b) radio frequency (RF) sputtering (dark area is ZnO) and (c) ALD (no $\mathrm{ZnO}$ damage) in LB media with the bacterial solution after two days. Reprinted with permission from (Kim et al., 2012). Copyright 2012 Elsevier.

Zhang et al. deposited an ultrathin $\mathrm{Al}_{2} \mathrm{O}_{3}$ layer on a AgFON substrate for SERS detection (Zhang et al., 2006). The $\mathrm{Al}_{2} \mathrm{O}_{3}$ layer was used to protect $\mathrm{Ag}$ against oxidation and allows preserving an excellent sensitivity. Also, the adsorption affinity of the anthrax biomarker detected in this study for the $\mathrm{Al}_{2} \mathrm{O}_{3}$ is five times stronger than that for the AgFON alone. The SERS substrate was later used for bacillus spores detection, and a limit of detection (LOD) of $\sim 1.4 \times 10^{3}$ spores was attained. The SERS substrate remained functional over a period of 9 months and opens up the possibility to be used for biomedical, homeland security, and environmental applications. 
These examples illustrate the feasibility of ALD to deposit highly dense and conformal films for the protection of biosensors. The improved long-term stability of ALD coated devices allows them to be reused without having a detrimental impact on their sensing performance and opens up the possibility for biosensors to be used for in vivo monitoring.

\section{Materials deposited by ALD}

The properties of materials at the nanoscale strongly depend on their size, shape, chemical composition, and surface area (Bechelany et al., 2015; S. Zhang et al., 2017). Thus, ALD has been extensively used to modify and enhance different electrical, optical, catalytical, and structural properties of biosensor materials (Chen et al., 2004; Cheun et al., 2010; O'Neill et al., 2015; Wang et al., 2012). In order to be used in biosensing applications, the materials need to be biocompatible with the biological components of the biosensor and shouldn't compromise the sensitivity and overall performance of these devices.

Due to the popularity of FET type biosensors(Li et al., 2018; Sarkar et al., 2014; Zafar et al., 2018), most of the applications of ALD in biosensing have been focused so far on depositing high dielectric materials. Nonetheless, materials with high refractive index and high catalytic activity have also been reported. In this section, the materials deposited by ALD to fabricate biosensors have been classified by their relevant property and are showcased with a few examples.

\subsection{Materials with high dielectric constant}

ALD has been used to deposit thin films of materials with high dielectric constant to reduce leakage current, passivate surfaces and, in some cases, serve as gate dielectrics (Kim et al., 2009; Ponraj et al., 2013). Examples of high $k$ oxides films deposited by ALD for the fabrication of biosensors are presented in Table 4.

Table 4. Examples of materials with high dielectric constant deposited by ALD for the fabrication of biosensors

\begin{tabular}{|c|c|c|c|c|c|c|}
\hline $\begin{array}{l}\text { Material } \\
\text { deposited } \\
\text { by ALD } \\
\end{array}$ & $\begin{array}{l}\text { Application } \\
\text { of the ALD } \\
\text { coating }\end{array}$ & Substrate/Probe & Analyte & Detection method & $\begin{array}{l}\text { Concentration } \\
\text { range/Detection } \\
\text { Limit }\end{array}$ & Ref. \\
\hline $\mathrm{Al}_{2} \mathrm{O}_{3}$ & $\begin{array}{l}\text { Current } \\
\text { leakage } \\
\text { prevention }\end{array}$ & $\begin{array}{l}\text { Silicon wire } \\
\text { FET/urease }\end{array}$ & Urea & $\begin{array}{l}\text { Electrochemical } \\
\text { (FET) }\end{array}$ & $0.1-0.68 \mathrm{mM}$ & $\begin{array}{l}\text { (Ch } \\
\text { en } \\
\text { et } \\
\text { al., } \\
200 \\
8)\end{array}$ \\
\hline $\begin{array}{l}\mathrm{Al}_{2} \mathrm{O}_{3} / \\
\mathrm{TiO}_{2}\end{array}$ & $\begin{array}{l}\text { Buffer layer } \\
\text { during } \\
\text { photolithogra } \\
\text { phic process } \\
\text { and current } \\
\text { leakage } \\
\text { decrease/film } \\
\text { for ZnO } \\
\text { stability }\end{array}$ & $\begin{array}{l}\text { Three-dimensional } \\
\text { (3D) bioelectronics- } \\
\text { FET (bio- } \\
\text { FET)/prostate } \\
\text { specific antigen - 1- } \\
\text { antichymotrypsin } \\
\text { (PSA-ACT) } \\
\text { antibody }\end{array}$ & $\begin{array}{l}\text { PSA-ACT } \\
\text { antigen }\end{array}$ & $\begin{array}{l}\text { Electrochemical } \\
\text { (FET) }\end{array}$ & $\begin{array}{l}\text { Dynamic range } \\
\text { of } 10^{7} \text { and } \\
\text { detection down } \\
\text { to the } \mathrm{fM} \text { level }\end{array}$ & $\begin{array}{l}(\mathrm{Ki} \\
\mathrm{m} \\
\text { et } \\
\text { al., } \\
201 \\
5)\end{array}$ \\
\hline $\mathrm{Al}_{2} \mathrm{O}_{3}$ & Current & Magnetic & Influenza & Magnetoelectric & Detection range & (Kri \\
\hline
\end{tabular}




\begin{tabular}{|c|c|c|c|c|c|c|}
\hline & $\begin{array}{l}\text { leakage } \\
\text { prevention }\end{array}$ & $\begin{array}{l}\text { nanoparticles } \\
\text { (MNPs)/Influenza A } \\
\text { capture antibody }\end{array}$ & $\begin{array}{l}\text { A viruses } \\
\text { (IAVs) }\end{array}$ & $\begin{array}{l}\text { (giant } \\
\text { magnetoresistance } \\
{[\mathrm{GMR}] \text { ) }}\end{array}$ & $\begin{array}{l}\text { of } 1.5 \times 10^{2} 50 \% \\
\text { tissue culture } \\
\text { infective dose } \\
(\text { TCID } 50) / \mathrm{ml} \text { up } \\
\text { to } 1.0 \times 10^{5} \\
\text { TCID } 50 / \mathrm{ml}\end{array}$ & $\begin{array}{l}\text { shn } \\
\text { a et } \\
\text { al., } \\
201 \\
6)\end{array}$ \\
\hline $\mathrm{Al}_{2} \mathrm{O}_{3}$ & $\begin{array}{l}\text { Insulating } \\
\text { layer, current } \\
\text { leakage } \\
\text { prevention }\end{array}$ & $\begin{array}{l}\text { Nickel } \\
\text { interdigitated } \\
\text { electrodes/ } \\
\mathrm{Al}_{2} \mathrm{O}_{3} / \mathrm{GSH}\end{array}$ & $\begin{array}{l}\text { glutathione } \\
\text { S- } \\
\text { transferase } \\
\text { (GST) }\end{array}$ & $\begin{array}{l}\text { Electrochemical } \\
\text { (impedance) }\end{array}$ & $\begin{array}{l}\text { Lowest } \\
\text { detectable value } \\
\text { (LDV) } 2 \times 10^{-10} \\
\mathrm{M} \\
\text { Highest } \\
\text { detectable value } \\
\text { (HDV) } 2 \times 10^{-6} \\
\mathrm{M}\end{array}$ & $\begin{array}{l}\text { (Ve } \\
\text { llo } \\
\text { et } \\
\text { al., } \\
201 \\
7)\end{array}$ \\
\hline $\mathrm{Al}_{2} \mathrm{O}_{3}$ & $\begin{array}{l}\text { Insulating and } \\
\mathrm{H}^{+} \text {ions } \\
\text { sensitive layer }\end{array}$ & $\begin{array}{l}\mathrm{SnO}_{2} \mathrm{NW}- \\
\text { FET/streptavidin }\end{array}$ & $\begin{array}{l}\text { Biotinylate } \\
\mathrm{d} \\
\text { tetracyclin } \\
\text { e repressor } \\
\text { protein } \\
\text { (bTetR) }\end{array}$ & $\begin{array}{l}\text { Electrochemical } \\
\text { (FET) }\end{array}$ & $\begin{array}{l}\text { Successful } \\
\text { detection of } 600 \\
\mu \mathrm{g} / \mathrm{ml}\end{array}$ & $\begin{array}{l}\text { (Jak } \\
\text { ob } \\
\text { et } \\
\text { al., } \\
201 \\
7)\end{array}$ \\
\hline $\mathrm{Al}_{2} \mathrm{O}_{3}$ & $\begin{array}{l}\text { Insulating } \\
\text { layer, gate } \\
\text { dielectric, } \\
\text { adhesion } \\
\text { improvement }\end{array}$ & $\begin{array}{l}\mathrm{MoS}_{2} / \text { anti-PSA } \\
\text { antibody }\end{array}$ & PSA & $\begin{array}{l}\text { Electrochemical } \\
\text { (FET) }\end{array}$ & $\begin{array}{l}\text { Down to } 1 \\
\mathrm{pg} / \mathrm{ml}\end{array}$ & $\begin{array}{l}\text { (Yo } \\
\text { o et } \\
\text { al., } \\
201 \\
7)\end{array}$ \\
\hline $\mathrm{HfO}_{2}$ & $\begin{array}{l}\text { Gate dielectric } \\
\text { material }\end{array}$ & Bio-FET & Biotin & $\begin{array}{l}\text { Electrochemical } \\
\text { (FET) }\end{array}$ & $\begin{array}{l}\text { Biotin } \\
\text { functionalizatio } \\
n\end{array}$ & $\begin{array}{l}\text { (Ch } \\
\text { en } \\
\text { et } \\
\text { al., } \\
201 \\
0)\end{array}$ \\
\hline $\mathrm{HfO}_{2}$ & $\begin{array}{l}\text { Passivation } \\
\text { film and gate } \\
\text { insulator }\end{array}$ & $\begin{array}{l}\text { Carbon nanotube } \\
\text { (CNT) FET/3- } \\
\text { Mercaptopropionic } \\
\text { acid }\end{array}$ & $\begin{array}{l}\text { Cytochrom } \\
\text { e C and } \\
\text { beta } \\
\text { lactoglobul } \\
\text { in A }\end{array}$ & $\begin{array}{l}\text { Electrochemical } \\
\text { (FET) }\end{array}$ & $\begin{array}{l}\text { Detection range } \\
\text { for cytochrome } \\
\mathrm{C}: 350 \mathrm{pM}-3 \\
\mu \mathrm{M} \\
\text { Detection range } \\
\text { for beta } \\
\text { lactoglobulin A : } \\
2.5 \mathrm{pM}-21 \mathrm{nM}\end{array}$ & $\begin{array}{l}(\mathrm{Na} \\
\text { kas } \\
\text { him } \\
\text { a et } \\
\text { al., } \\
201 \\
0)\end{array}$ \\
\hline $\mathrm{HfO}_{2}$ & $\begin{array}{l}\text { Reduction of } \\
\text { current } \\
\text { leakage and } \\
\text { enhancer of } \\
\text { gate } \\
\text { capacitance }\end{array}$ & $\begin{array}{l}\text { Silicon } \\
\text { wafer/ } \mathrm{HfO}_{2} / \text { anti- } \\
\text { human interleukin- } \\
10 \text { (IL-10) } \\
\text { monoclonal } \\
\text { antibody }(\mathrm{mAb})\end{array}$ & $\begin{array}{l}\text { Recombina } \\
\text { nt human } \\
\text { (rH) IL-10 }\end{array}$ & $\begin{array}{l}\text { Electrochemical } \\
\text { (impedance) }\end{array}$ & $\begin{array}{l}\text { Linear range of } \\
\text { detection of } 0.1 \\
-20 \mathrm{pg} / \mathrm{ml}\end{array}$ & $\begin{array}{l}(\text { Le } \\
\text { e et } \\
\text { al., } \\
201 \\
2)\end{array}$ \\
\hline $\mathrm{HfO}_{2}$ & $\begin{array}{l}\text { Gate dielectric } \\
\text { layer, } \\
\text { protection of } \\
\text { electrodes } \\
\text { from liquid } \\
\text { environment }\end{array}$ & $\begin{array}{l}\mathrm{MoS}_{2} \text { nanosheet } \\
\text { FET/monoclonal } \\
\text { PSA }\end{array}$ & $\begin{array}{l}\text { Cancer } \\
\text { marker } \\
\text { protein } \\
\text { PSA }\end{array}$ & $\begin{array}{l}\text { Electrochemical } \\
\text { (FET) }\end{array}$ & $\begin{array}{l}\text { Detection down } \\
\text { to } 375 \mathrm{fM}\end{array}$ & $\begin{array}{l}\text { (W } \\
\text { ang } \\
\text { et } \\
\text { al., } \\
201 \\
4)\end{array}$ \\
\hline $\mathrm{HfO}_{2}$ & $\begin{array}{l}\text { Reduction of } \\
\text { leakage } \\
\text { current }\end{array}$ & $\begin{array}{l}\text { MoS2 FET/anti- } \\
\text { human TNF- } \alpha\end{array}$ & $\begin{array}{l}\text { Human } \\
\text { TNF- } \alpha\end{array}$ & $\begin{array}{l}\text { Electrochemical } \\
\text { (FET) }\end{array}$ & $\begin{array}{l}\text { Detection down } \\
\text { to the } \mathrm{fM} \text { level }\end{array}$ & $\begin{array}{l}(\mathrm{Na} \\
\mathrm{m} \\
\text { et } \\
\text { al., } \\
201\end{array}$ \\
\hline
\end{tabular}




\begin{tabular}{|c|c|c|c|c|c|c|}
\hline & & & & & & 5) \\
\hline $\mathrm{ZrO}_{2}$ & Gate insulator & $\begin{array}{l}\text { Potassium-doped } \\
\text { polypyrrole/carbon } \\
\text { nanotube/cholestero } \\
\text { l oxidase }(\mathrm{ChO})\end{array}$ & Cholesterol & $\begin{array}{l}\text { Electrochemical } \\
\text { (FET) }\end{array}$ & $\begin{array}{l}\text { Linear range of } \\
0.5-20 \mathrm{mM} \\
\text { Sensitivity of } \\
400(\mu \mathrm{A} / \mathrm{mM} \\
\left.\mathrm{mm}^{2}\right)\end{array}$ & $\begin{array}{l}\text { (Ba } \\
\text { rik } \\
\text { et } \\
\text { al., } \\
201 \\
4)\end{array}$ \\
\hline $\mathrm{ZrO}_{2}$ & $\begin{array}{l}\text { Insulating } \\
\text { layer }\end{array}$ & $\begin{array}{l}\text { Polydimethlsiloxane } \\
\text { (PDMS) } \\
\text { microwells/gold } \\
\text { electrodes }\end{array}$ & $\begin{array}{l}\text { Normal } \\
\text { human } \\
\text { dermal } \\
\text { fibroblast } \\
\text { (NHDF) } \\
\text { and human } \\
\text { lung } \\
\text { adenocarci } \\
\text { noma } \\
\text { epithelial } \\
\text { (H441) }\end{array}$ & $\begin{array}{l}\text { Electrochemical } \\
\text { (impedance) }\end{array}$ & $\begin{array}{l}\text { Successful cell } \\
\text { analysis for } \\
\text { nanotoxicologic } \\
\text { al studies }\end{array}$ & $\begin{array}{l}\text { (Sti } \\
\text { cke } \\
\text { r et } \\
\text { al., } \\
201 \\
5)\end{array}$ \\
\hline
\end{tabular}

One of the most used high $k$ oxides is $\mathrm{Al}_{2} \mathrm{O}_{3}$ (Knez et al., 2007; Yan Zhao et al., 2013). Due to its high breakdown field and high thermal stability, $\mathrm{Al}_{2} \mathrm{O}_{3}$ deposited by ALD can successfully reduce surface leakage current (Ye et al., 2003). Another positive aspect of this material for biosensing is the fact that $\mathrm{Al}_{2} \mathrm{O}_{3}$ films by ALD present good biocompatibility (Finch et al., 2008). Chen et al. deposited a $10 \mathrm{~nm}$ film of $\mathrm{Al}_{2} \mathrm{O}_{3}$ to prevent current leakage between silicon nanowires and analyte solution in a FET biosensor for urea detection (Chen et al., 2008). The $\mathrm{Al}_{2} \mathrm{O}_{3}$ film was later treated with oxygen plasma (to clean it and render its surface hydrophilic) before functionalization with 3-aminopropyltriethoxy silane (APTES) and urease enzyme. Krishna et al. developed a GMR biosensor based on magnetic nanoparticles for detection of influenza A virus (Krishna et al., 2016). In their work, they deposited an $18 \mathrm{~nm}$ thick $\mathrm{Al}_{2} \mathrm{O}_{3}$ film onto a GMR chip to prevent current leakage. Vello et al. deposited a $3.3 \mathrm{~nm}$ $\mathrm{Al}_{2} \mathrm{O}_{3}$ insulating film on nickel interdigitated electrodes to prevent leakage current and enable them to operate in an aqueous buffered medium (Vello et al., 2017). To obtain this, they immersed the interdigitated electrodes coated with $\mathrm{Al}_{2} \mathrm{O}_{3}$ in a phosphate buffered saline (PBS) solution while applying $1 \mathrm{~V}$ to the pads of the device. The $\mathrm{Al}_{2} \mathrm{O}_{3}$ coated electrodes were functionalized with tripeptide reduced glutathione (GSH) to detect the target enzyme GST by evaluating variations on the overall capacitance values. The biosensor could detect GST at concentrations as low as $200 \mathrm{pmol} / \mathrm{L}$ (the lowest value reported according to references) and could be easily regenerated to be used several times. Yoo et al. deposited an $\mathrm{Al}_{2} \mathrm{O}_{3}$ layer on an $\mathrm{SU}-8$ organic layer to fabricate a hybrid gate dielectric

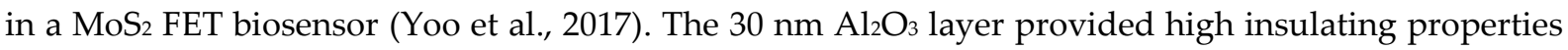
and improved the adhesion between the organic SU-8 layer and the MoS 2 /source-drain electrodes multilayer. Figure 8 shows the different layers of the epidermal skin-type $\mathrm{MoS}_{2}$ biosensor. The flexible biochip was used for real-time detection of PSA with concentrations as low as $1 \mathrm{pg} / \mathrm{ml}$, which is much lower than the value needed for clinical trials $(\sim 4 \mathrm{ng} / \mathrm{ml})$. In addition, they introduced a commercial light-emitting diode (LED) to provide a direct diagnostic result, which opens up the possibility to use this type of biosensors in point-of-care (POC) and forensic applications. 
(a)

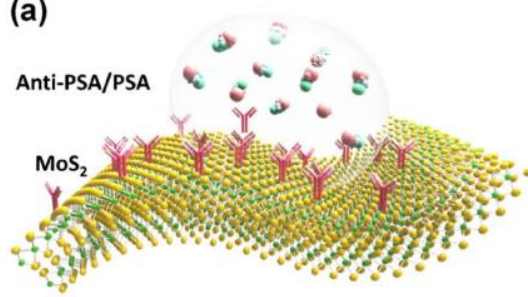

(b)

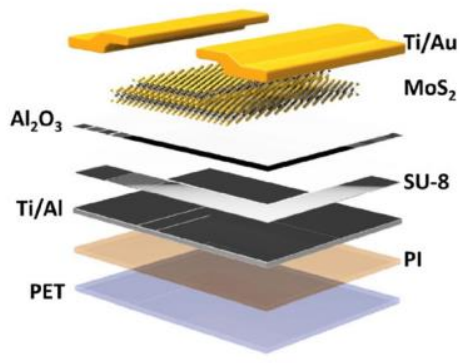

(c)

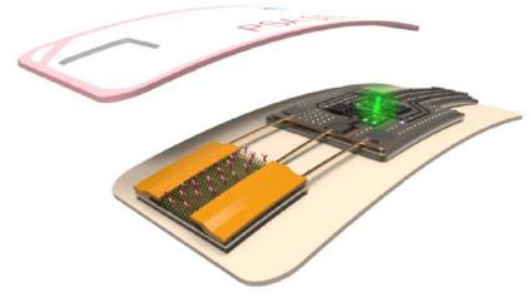

(d)

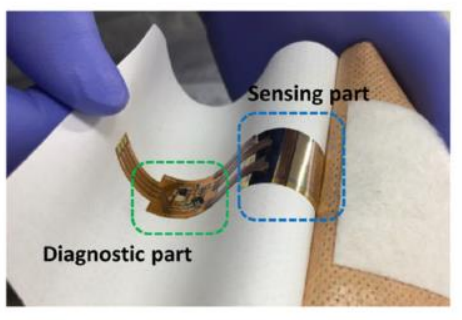

(e)

(f)
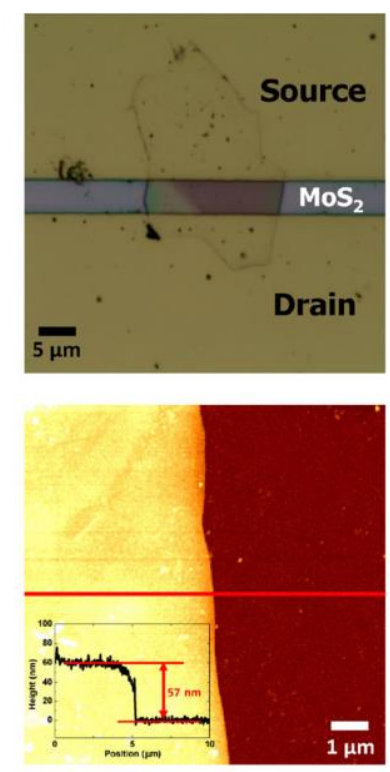

Figure 8. Illustration and demonstration of the platform of an epidermal skin-type MoS2. (a) Schematic of the PSA binding with the PSA antibody functionalized on the MoS2 surface. (b) and (c) schematic layout of the 2D multilayer $\mathrm{MoS}_{2}$ FETs. Photograph (d) of an epidermal skin-type $\mathrm{MoS}_{2}$ biosensor system consisting of the biosensor, read-out circuits, and an LED as an indicator. (e) Optical image and (f) AFM image of a flexible MoS2 device. Reprinted with permission from (Yoo et al., 2017). Copyright 2017 Springer Nature.

Another high $k$ material that has been deposited by ALD for biosensing applications is $\mathrm{HfO}_{2}$. $\mathrm{HfO}_{2}$ is known for its thermodynamic stability when deposited on $\mathrm{Si}$, which effectively reduces leakage current and makes it suitable as a gate material for metal-oxide-semiconductor (MOS) devices (Aarik et al., 2004; Green et al., 2002; Gusev et al., 2003; Gutowski et al., 2002). Also, $\mathrm{HfO}_{2}$ has an isoelectric point around $\mathrm{pH} 7$ that makes it uncharged in many biological solutions and can be functionalized with biomolecules (Chen et al., 2010). Lee et al. developed a biosensor based on $\mathrm{HfO}_{2}$ for human IL-10 detection by electrochemical impedance spectroscopy (EIS) (Lee et al., 2012). They deposited a $10.7 \mathrm{~nm}$ film of $\mathrm{HfO}_{2}$ on a silicon wafer which was later functionalized with self-assembled monolayers (SAMs) of an aldehyde-silane (11-(triethoxysilyl) undecanal (TESUD)) and anti-human IL-10 mAb. By following the EIS of the modified $\mathrm{HfO}_{2}$ with increasing human-IL10 concentrations, they demonstrated that the biosensor had a working linear range of $0.1-20 \mathrm{pg} / \mathrm{ml}$ and a sensitivity of $0.49(\mathrm{ng} / \mathrm{ml})^{-1}$. Wang et al. reported a label-free $\mathrm{MoS}_{2}$ nanosheet-based FET biosensor covered with a 7-8 nm layer of $\mathrm{HfO}_{2}$ (Wang et al., 2014). Figure 9 shows the homebuilt microfluidic channel system where sample solutions were flowed to be detected by the active area. Figure 6c shows the different layers that make up the FET biosensor. They used $\mathrm{HfO}_{2}$ to serve as the gate dielectric layer, to protect the metal electrodes from a fluidic environment, and to serve as a starting layer for functionalization with silanes. The FET biosensor showed good sensitivity (down to the femtomolar level) to cancer marker protein PSA and high selectivity by not responding to BSA protein. 


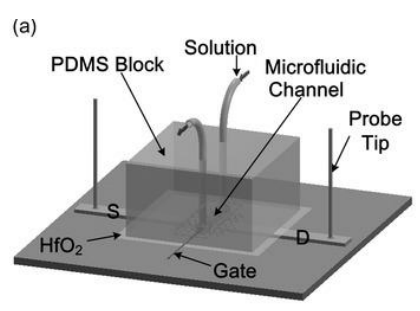

(b)

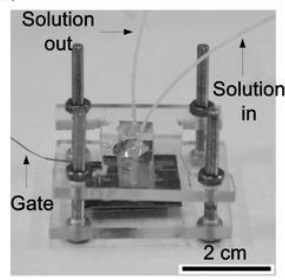

(c)

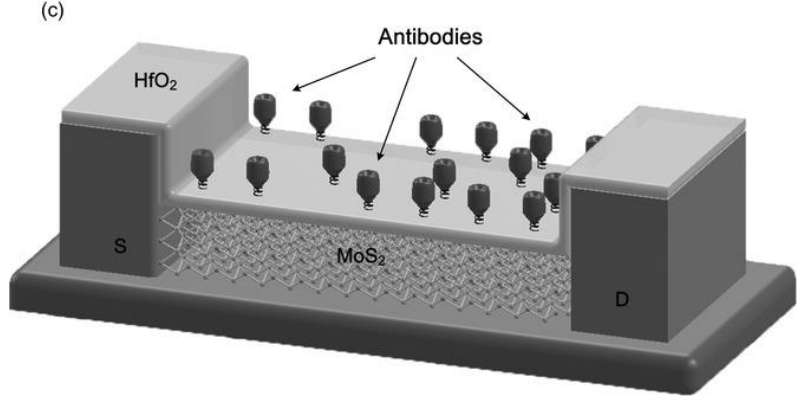

Figure 9. Schematic (a) and photo (b) of the biosensor configuration. (c) Schematic of the biofunctionalization layers on the device surface (S [source]; D [drain]). Reprinted with permission from (Wang et al., 2014). Copyright 2014 John Wiley and Sons.

Besides $\mathrm{Al}_{2} \mathrm{O}_{3}$ and $\mathrm{HfO}_{2}$, $\mathrm{ALD}$ of $\mathrm{ZrO}_{2}$ has also been reported for biosensors fabrication. Thanks to its large energy bandgap and thermodynamic stability, $\mathrm{ZrO}_{2}$ has been considered as an alternative gate dielectric material (Kukli et al., 2002; Nam and Rhee, 2004; Niinistö et al., 2004). Barik et al. deposited $\mathrm{ZrO}_{2}$ by ALD as gate insulator on an enzyme FET (ENFET) biosensor (Barik et al., 2014). They deposited $\mathrm{ZrO}_{2}$ on the channel region of the biosensor to increase its capacitance and thus gain sensitivity. Sticker et al. deposited a $15 \mathrm{~nm}$ thick $\mathrm{ZrO}_{2}$ insulation layer on interdigitated microelectrodes for nanotoxicological cell analysis (Sticker et al., 2015). By running computational simulations, they showed that insulated interdigitated electrode structures had an improved electrical current distribution when compared to bare electrodes. They successfully evaluated the toxicity of silica nanoparticles (with and without protein coatings) on H441 cells by monitoring the impedance signal over time.

The numerous examples of biosensors that employ high $k$ oxides films prepared by ALD highlight the importance of this technique for the fabrication of these devices. Moreover, the conformal and pinhole free thin films of metal oxides successfully passivate the surface of the biosensors without loss of sensitivity and make them promising for miniaturized POC diagnostics.

\subsection{Materials with high refractive index}

Materials deposited by ALD with high refractive index have been used in optical applications (Alasaarela et al., 2010; Zhu et al., 2016) and microelectromechanical systems (Rissanen et al., 2012). Owing to the smoothness of the films and the ability to coat complex-shaped substrates with a precise thickness control, ALD has been preferred over other thin film deposition techniques like dip coating and self-assembly (Sobel and Hess, 2015; Ying Zhao et al., 2013). Examples of high refractive index films deposited by ALD for the fabrication of biosensors are presented in Table 5. Recently, Oubaha et al. deposited a $\mathrm{Ta}_{2} \mathrm{O}_{5}$ layer by ALD to increase the sensing properties of a multianalyte biosensor (Oubaha et al., 2015). $\mathrm{Ta}_{2} \mathrm{O}_{5}$ was chosen due to its high refractive index, which increases the intensity of the evanescent field (EF) by 440 times when compared to the system without the high refractive 
index layer (HRIL). The thickness of the HRIL chosen for this work was $35 \mathrm{~nm}$ because it provides the maximum evanescent wave enhancement. Cy-5-labeled mouse IgG antibody was detected through fluorescence detection, and a limit of detection of $0.25 \mu \mathrm{g} / \mathrm{ml}$ was achieved. Smietana et al. deposited an ALD layer of $\mathrm{TiO}_{2}$ on LPGs for a label-free optical biosensor (Smietana et al., 2015). $\mathrm{TiO}_{2}$ was used for improving the refractive index sensitivity of the biosensor and as a biocompatible material for endotoxin binding protein (adhesin) functionalization. The deposition of a $70 \mathrm{~nm}$ thick $\mathrm{TiO}_{2}$ layer on the LPG increased the refractive index sensitivity 2.8 times when compared to the bare LPG. Binding of E. coli B lipopolysaccharide (LPS) to bacteria adhesion was confirmed thanks to an increase in the spectral separation of resonances.

Table 5. Examples of materials with high refractive index deposited by ALD for the fabrication of biosensors

\begin{tabular}{|c|c|c|c|c|c|c|}
\hline $\begin{array}{l}\text { Material } \\
\text { deposited } \\
\text { by ALD } \\
\end{array}$ & $\begin{array}{l}\text { Application of } \\
\text { the ALD coating }\end{array}$ & Substrate/Probe & Analyte & $\begin{array}{l}\text { Detection } \\
\text { Method }\end{array}$ & $\begin{array}{l}\text { Concentration } \\
\text { range/Detection } \\
\text { Limit }\end{array}$ & Ref. \\
\hline $\mathrm{Ta}_{2} \mathrm{O}_{5}$ & EF enhancement & $\begin{array}{l}\text { Waveguide-based } \\
\text { photonic } \\
\text { platform/Cy5- } \\
\text { labelled anti-mouse } \\
\text { IgG antibody }\end{array}$ & $\begin{array}{l}\text { Mouse } \\
\text { IgG } \\
\text { antigen }\end{array}$ & $\begin{array}{l}\text { Optical } \\
\text { (fluorescence) }\end{array}$ & $\begin{array}{l}\text { Limit of } \\
\text { detection of } 0.25 \\
\mu \mathrm{g} / \mathrm{ml}\end{array}$ & $\begin{array}{l}(\mathrm{Ou} \\
\text { bah } \\
\text { a et } \\
\text { al., } \\
201 \\
5)\end{array}$ \\
\hline $\mathrm{TiO}_{2}$ & $\begin{array}{l}\text { Improvement of } \\
\text { refractive index } \\
\text { sensitivity }\end{array}$ & $\begin{array}{l}\mathrm{LPG} / \mathrm{TiO}_{2} / \text { E. coli } \mathrm{B} \\
\text { bacteriophage g37 } \\
\text { adhesin }\end{array}$ & $\begin{array}{l}\text { E. coli B } \\
\text { LPS }\end{array}$ & $\begin{array}{l}\text { Optical } \\
\text { (refractive } \\
\text { index) }\end{array}$ & $\begin{array}{l}\text { Positive test for } \\
\text { adhesin-LPS } \\
\text { binding }\end{array}$ & $\begin{array}{l}\text { (S } \\
\text { mie } \\
\text { tan } \\
\text { a et } \\
\text { al., } \\
201 \\
5)\end{array}$ \\
\hline
\end{tabular}

\subsection{Materials with catalytic activity}

ALD has been used to improve the catalytic activity of materials thanks to its ability to precisely control the catalyst particles properties and uniform dispersion on the surface of the support (Sun et al., 2013; Weber et al., 2015, 2012). Examples of materials with catalytic activity deposited by ALD for the fabrication of biosensors are presented in Table 6. Recently, Choi et al. reported the decoration of CNTs with Ni nanoparticles by ALD for non-enzymatic glucose sensing (Choi et al., 2015). The presence of Ni nanoparticles on CNTs was confirmed by TEM, high-angle annular dark-field (HAADF), and energy-dispersive X-ray spectrometry (EDX). The $\sim 8 \mathrm{~nm} \mathrm{Ni} \mathrm{nanoparticles} \mathrm{were}$ uniformly distributed on the walls of the CNTs. The selectivity of the sensor was confirmed by showing minimum changes in the oxidation current when adding ascorbic acid or uric acid, whereas, in the case of glucose, the value of the oxidation current was far more important. The sensor presented a detection limit of $2 \mu \mathrm{M}$ and a linear range of $0.005-2 \mathrm{mM}$. Furthermore, it showed a rapid response and repeatability for non-enzymatic detection of glucose.

At the nanoscale, both mass transport and electron transport play a crucial role in obtaining excellent electrocatalytic properties. Nanoporous metals decorated with transition-metal oxides have been proposed as structures that can serve as electrochemical biosensors. Zhang et al. deposited a CoO layer on nanoporous gold (NPG) for the detection of glucose and $\mathrm{H}_{2} \mathrm{O}_{2}$ (Zhang et al., 2016). The $\mathrm{Au}$ nanopores with a size ranging between 40-100 nm were covered with 100-800 cycles of CoO. When less than 200 cycles were used, the amorphous $\mathrm{CoO}$ formed a discontinuous layer. On the other hand, 
a continuous layer was observed at higher cycles. The NPG/CoO heterostructure showed an excellent electrocatalytic activity of glucose oxidation owing to the interconnected Au skeletons and the synergistic effect between $\mathrm{Au}$ and $\mathrm{CoO}$. Furthermore, the electrochemical biosensor could detect concentrations of $\mathrm{H}_{2} \mathrm{O}_{2}$ as low as $0.1 \mathrm{mM}$ and its sensitivity was comparable to other types of composite electrodes based on graphene sheets, noble metals, and metal oxide nanoparticles.

Table 6. Examples of materials with catalytic activity deposited by ALD for the fabrication of biosensors

\begin{tabular}{|c|c|c|c|c|c|c|}
\hline $\begin{array}{l}\text { Material } \\
\text { deposited } \\
\text { by ALD } \\
\end{array}$ & $\begin{array}{l}\text { Application of } \\
\text { the ALD coating }\end{array}$ & Substrate/Probe & Analyte & $\begin{array}{l}\text { Detection } \\
\text { Method }\end{array}$ & $\begin{array}{l}\text { Concentration } \\
\text { range/Detection } \\
\text { Limit }\end{array}$ & Ref. \\
\hline $\mathrm{CoO}$ & $\begin{array}{l}\text { Electrode body, } \\
\text { catalytic activity }\end{array}$ & NPG/CoO & $\mathrm{H}_{2} \mathrm{O}_{2}$ & $\begin{array}{l}\text { Electrochemical } \\
\text { (current) }\end{array}$ & $\begin{array}{l}\text { Linear range of } \\
\text { detection } 0.1- \\
92.9 \mathrm{mM}\end{array}$ & $\begin{array}{l}\text { (Zh } \\
\text { ang } \\
\text { et } \\
\text { al., } \\
201 \\
6)\end{array}$ \\
\hline $\mathrm{Ni}$ & $\begin{array}{l}\text { Electrocatalyst } \\
\text { for glucose } \\
\text { oxidation }\end{array}$ & $\begin{array}{l}\text { CNT-Ni } \\
\text { nanocomposites }\end{array}$ & Glucose & $\begin{array}{l}\text { Electrochemical } \\
\text { (current) }\end{array}$ & $\begin{array}{l}\text { Linear range of } \\
\text { detection of } \\
0.005-2 \mathrm{mM} \\
\text { Detection limit of } \\
2 \mu \mathrm{M}\end{array}$ & $\begin{array}{l}\text { (Ch } \\
\text { oi } \\
\text { et } \\
\text { al., } \\
201 \\
5)\end{array}$ \\
\hline $\mathrm{NiO}$ & $\begin{array}{l}\text { Electrocatalyst } \\
\text { for glucose } \\
\text { oxidation }\end{array}$ & $\begin{array}{l}\mathrm{NiO} / \mathrm{SiC} \\
\text { nanocomposite }\end{array}$ & Glucose & $\begin{array}{l}\text { Electrochemical } \\
\text { (current) }\end{array}$ & $\begin{array}{l}\text { Linear range of } \\
\text { detection of } \\
0.004-7.5 \mathrm{mM} \\
\text { Detection limit of } \\
0.32 \mu \mathrm{M}\end{array}$ & $\begin{array}{l}\text { (Ya } \\
\text { ng } \\
\text { et } \\
\text { al., } \\
201 \\
5)\end{array}$ \\
\hline
\end{tabular}

\section{Conclusions and future perspectives}

ALD has rapidly become a valuable technique for the fabrication of biosensors thanks to its ability to deposit a wide range of materials with precise thickness control and excellent conformality. In this minireview, the crucial role of ALD for the fabrication of different types of nanostructured biosensors and its capability to improve their sensing properties has been shown. Immobilization of biorecognition elements has also been demonstrated on layers deposited by ALD thanks to their biocompatibility and controlled chemical composition. The continuous miniaturization trend of biosensor devices and the complexity of the structures to coat demand high conformality, uniformity, and film quality that conventional thin film deposition techniques such as chemical vapor deposition (CVD) and physical vapor deposition (PVD) cannot achieve (Crowell, 2003). However, there are still some challenges to overcome. ALD remains a slow technique and requires vacuum conditions that make the processes somewhat expensive and difficult to scale up (Muñoz-Rojas and MacManusDriscoll, 2014). Different approaches such as spatial atmospheric ALD (Hoffmann et al., 2018; Hoye et al., 2015; Poodt et al., 2012), roll-to-roll systems (Ali et al., 2014; Maydannik et al., 2014), and rotating reactors (Longrie et al., 2014; Sharma et al., 2015) are being developed to make the process (even) more scalable and compatible with industrial requirements. Additionally, the design and synthesis of new and affordable precursors are needed to further increase the availability of materials that can be deposited. This is a difficult task given the constraints that the ALD reaction imposes on the precursors. The chemicals must be volatile at room temperature (or by being slightly heated) and 
thermally stable. Also, they must react quickly with the substrate to allow surface saturation and provide a fast growth (Johnson et al., 2014; Leskelä and Ritala, 2002; Marichy et al., 2012).

Also, while some biosensors have passed the testing phase and have become available in healthcare applications as handheld devices or portable units (Ronkainen et al., 2010), their design must still be improved so they can diversify their applications in fields such as environmental monitoring, security and bioterrorism, and food safety. Finally, it is safe to say that ALD (in combination with other fabrication techniques) will push biosensors past the limitations they currently face by providing robust, sensible, and selective platforms that will become part of our everyday lives.

\section{Acknowledgment}

Octavio Graniel would like to thank CONACYT for funding. This work was supported by the European project "CanBioSe, Project ID: 778157".

\begin{tabular}{ll}
\hline List of acronyms & \\
\hline Acronym & Full name \\
\hline 3D & three dimensional \\
AAO & anodic aluminum oxide \\
AgFON & silver film-over-nanosphere \\
ALD & atomic layer deposition \\
ALE & atomic layer epitaxy \\
APTES & 3-aminopropyltriethoxy silane \\
BEL & band edge laser \\
Bio-FET & bioelectronics field effect transistor \\
BSA & bovine serum albumin \\
bTetR & biotinylated tetracycline repressor protein \\
CaDPA & calcium dipicolinate \\
ChOx & cholesterol oxidase \\
CNT & carbon nanotube \\
CVD & chemical vapor deposition \\
DPV & differential pulse voltammetry \\
EDX & energy-dispersive X-ray spectrometry \\
EF & evanescent field \\
EIS & electrochemical impedance spectroscopy \\
ENFET & enzyme field effect transistor \\
FET & field effect transistor \\
GMR & giant magnetoresistance \\
GOx & glucose oxidase \\
GSH & tripeptide reduced glutathione \\
GST & glutathione-S-transferase \\
GVA & Grapevine virus A-type \\
H441 & human lung adenocarcinoma epithelial \\
HAADF & high-angle annular dark-field \\
HDV & highest detectable value \\
HRIL & high refractive index layer \\
IAVs & Influenza A viruses \\
IgG & immunoglobulin G \\
IL-10 & interleukin-10 \\
\hline & \\
\hline
\end{tabular}




\begin{tabular}{ll}
\hline LB & Lysogeny Broth \\
LDV & lowest detectable value \\
LED & light-emitting diode \\
MBS & 3-mal- eimidobenzoic acid N-hydroxysuccinimide ester \\
ML & molecular layering \\
MNPs & magnetic nanoparticles \\
MOS & metal-oxide-semiconductor \\
MQW & multiple quantum well \\
NHDF & normal human dermal fibroblast \\
NPG & nanoporous gold \\
NSL & nanosphere lithography \\
PBS & phosphate buffered saline \\
PC & photonic crystal \\
PDMS & polydimethylsiloxane \\
PET & poly(ethylene terephthalate) \\
POC & point-of-care \\
PSA & prostate specific antigen \\
PSA-ACT & prostate specific antigen/1-antichymotrypsin \\
PVD & physical vapor deposition \\
\hline SAPE & streptavidin tagged with phosphor \\
SAW & surface acoustic wave \\
SWV & square wave voltammetry \\
TCID & tissue culture infective dose \\
TEM & transmission electron microscopy \\
TESUD & 11-(triethoxysilyl) undecanal \\
XPS & (X-ray photoelectron spectroscopy) \\
\hline
\end{tabular}

\section{Bibliography}

Aaltonen, T., Ritala, M., Tung, Y.L., Chi, Y., Arstila, K., Meinander, K., Leskelä, M., 2004. Atomic layer deposition of noble metals: Exploration of the low limit of the deposition temperature. J. Mater. Res. 19, 3353-3358. https://doi.org/10.1557/JMR.2004.0426

Aarik, J., Mändar, H., Kirm, M., Pung, L., 2004. Optical characterization of $\mathrm{HfO}_{2}$ thin films grown by atomic layer deposition. Thin Solid Films 466, 41-47. https://doi.org/10.1016/j.tsf.2004.01.110

Alasaarela, T., Saastamoinen, T., Hiltunen, J., Säynätjoki, A., Tervonen, A., Stenberg, P., Kuittinen, M., Honkanen, S., 2010. Atomic layer deposited titanium dioxide and its application in resonant waveguide grating. Appl. Opt. 49, 4321-5. https://doi.org/10.1364/AO.49.004321

Ali, K., Choi, K.-H., Jo, J., Lee, Y.W., 2014. High rate roll-to-roll atmospheric atomic layer deposition of $\mathrm{Al}_{2} \mathrm{O}_{3}$ thin films towards gas diffusion barriers on polymers. Mater. Lett. 136, 90-94. https://doi.org/10.1016/J.MATLET.2014.07.186

Archibald, M.M., Rizal, B., Connolly, T., Burns, M.J., Naughton, M.J., Chiles, T.C., 2015. A nanocoaxial-based electrochemical sensor for the detection of cholera toxin. Biosens. Bioelectron. 74, 406-410. https://doi.org/10.1016/j.bios.2015.06.069

Arya, S.K., Saha, S., Ramirez-Vick, J.E., Gupta, V., Bhansali, S., Singh, S.P., 2012. Recent advances in $\mathrm{ZnO}$ nanostructures and thin films for biosensor applications: Review. Anal. Chim. Acta 737, 121. https://doi.org/10.1016/j.aca.2012.05.048

Balme, S., Picaud, F., Manghi, M., Palmeri, J., Bechelany, M., Cabello-Aguilar, S., Abou-Chaaya, A., Miele, P., Balanzat, E., Janot, J.M., 2015. Ionic transport through sub-10nm diameter hydrophobic 
high-aspect ratio nanopores: Experiment, theory and simulation. Sci. Rep. 5, 10135.

https://doi.org/10.1038/srep10135

Banerjee, P., Perez, I., Henn-Lecordier, L., Lee, S.B., Rubloff, G.W., 2009. Nanotubular metal-insulatormetal capacitor arrays for energy storage. Nat. Nanotechnol. 4, 292-296.

https://doi.org/10.1038/nnano.2009.37

Barik, M.A., Sarma, M.K., Sarkar, C.R., Dutta, J.C., 2014. Highly Sensitive Potassium-Doped Polypyrrole/Carbon Nanotube-Based Enzyme Field Effect Transistor (ENFET) for Cholesterol Detection. Appl. Biochem. Biotechnol. 174, 1104-1114. https://doi.org/10.1007/s12010-014-1029-5

Bechelany, M., Balme, S., Miele, P., 2015. Atomic layer deposition of biobased nanostructured interfaces for energy, environmental and health applications. Pure Appl. Chem. 87, 751-758. https://doi.org/10.1515/pac-2015-0102

Black, A., Urbanos, F.J., Osorio, M.R., Miranda, R., Vázquez De Parga, A.L., Granados, D., 2018. Encapsulating Chemically Doped Graphene via Atomic Layer Deposition. ACS Appl. Mater. Interfaces 10, 8190-8196. https://doi.org/10.1021/acsami.7b18709

Brétangol, F., Valsesia, A., Ceccone, G., Colpo, P., Gilliland, D., Ceriotti, L., Hasiwa, M., Rossi, F., 2006. Surface functionalization and patterning techniques to design interfaces for biomedical and biosensor applications. Plasma Process. Polym. 3, 443-455.

https://doi.org/10.1002/ppap.200600015

Cabello-Aguilar, S., Balme, S., Chaaya, A.A., Bechelany, M., Balanzat, E., Janot, J.M., Pochat-Bohatier, C., Miele, P., Dejardin, P., 2013. Slow translocation of polynucleotides and their discrimination by $\alpha$-hemolysin inside a single track-etched nanopore designed by atomic layer deposition. Nanoscale 5, 9582-9586. https://doi.org/10.1039/c3nr03683a

Cha, H., Lee, J., Jordan, L.R., Lee, S.H., Oh, S.-H., Kim, H.J., Park, J., Hong, S., Jeon, H., 2015. Surface passivation of a photonic crystal band-edge laser by atomic layer deposition of $\mathrm{SiO}_{2}$ and its application for biosensing. Nanoscale 7, 3565-3571. https://doi.org/10.1039/C4NR07552H

Chaaya, A.A., Viter, R., Baleviciute, I., Bechelany, M., Ramanavicius, A., Gertnere, Z., Erts, D., Smyntyna, V., Miele, P., 2014. Tuning Optical Properties of $\mathrm{Al}_{2} \mathrm{O}_{3} / \mathrm{ZnO}$ Nanolaminates Synthesized by Atomic Layer Deposition. J. Phys. Chem. C 118, 3811-3819. https://doi.org/10.1021/jp411970w

Chalker, P.R., 2016. Photochemical atomic layer deposition and etching. Surf. Coatings Technol. 291, 258-263. https://doi.org/10.1016/j.surfcoat.2016.02.046

Chen, P., Mitsui, T., Farmer, D.B., Golovchenko, J., Gordon, R.G., Branton, D., 2004. Atomic layer deposition to fine-tune the surface properties and diameters of fabricated nanopores. Nano Lett. 4, 1333-1337. https://doi.org/10.1021/n10494001

Chen, Y., Wang, X., Hong, M., Erramilli, S., Mohanty, P., 2008. Surface-modified silicon nano-channel for urea sensing. Sensors Actuators B Chem. 133, 593-598. https://doi.org/10.1016/j.snb.2008.03.033

Chen, Y.W., Liu, M., Kaneko, T., McIntyre, P.C., 2010. Atomic Layer Deposited Hafnium Oxide Gate Dielectrics for Charge-Based Biosensors. Electrochem. Solid-State Lett. 13, G29-G32. https://doi.org/10.1149/1.3280224

Cheun, H., Fuentes-Hernandez, C., Zhou, Y., Potscavage, W.J., Kim, S.J., Shim, J., Dindar, A., Kippelen, B., 2010. Electrical and optical properties of $\mathrm{ZnO}$ processed by atomic layer deposition 
in inverted polymer solar cells. J. Phys. Chem. C 114, 20713-20718.

https://doi.org/10.1021/jp106641j

Choi, T., Kim, S.H., Lee, C.W., Kim, H., Choi, S.K., Kim, S.H., Kim, E., Park, J., Kim, H., 2015. Synthesis of carbon nanotube-nickel nanocomposites using atomic layer deposition for high-performance non-enzymatic glucose sensing. Biosens. Bioelectron. 63, 325-330. https://doi.org/10.1016/j.bios.2014.07.059

Crowell, J.E., 2003. Chemical methods of thin film deposition: Chemical vapor deposition, atomic layer deposition, and related technologies. J. Vac. Sci. Technol. A Vacuum, Surfaces, Film. 21, S88-S95. https://doi.org/10.1116/1.1600451

Dekker, C., 2007. Solid-state nanopores. Nat. Nanotechnol. 2, 209-215. https://doi.org/10.1038/nnano.2007.27

Díaz, B., Światowska, J., Maurice, V., Seyeux, A., Härkönen, E., Ritala, M., Tervakangas, S., Kolehmainen, J., Marcus, P., 2013. Tantalum oxide nanocoatings prepared by atomic layer and filtered cathodic arc deposition for corrosion protection of steel: Comparative surface and electrochemical analysis. Electrochim. Acta 90, 232-245. https://doi.org/10.1016/j.electacta.2012.12.007

Dominik, M., Leśniewski, A., Janczuk, M., Niedziółka-Jönsson, J., Hołdyński, M., Wachnicki, Ł., Godlewski, M., Bock, W.J., Śmietana, M., 2017. Titanium oxide thin films obtained with physical and chemical vapour deposition methods for optical biosensing purposes. Biosens. Bioelectron. 93, 102-109. https://doi.org/10.1016/j.bios.2016.09.079

Elam, J.W., Xiong, G., Han, C.Y., Wang, H.H., Birrell, J.P., Welp, U., Hryn, J.N., Pellin, M.J., Baumann, T.F., Poco, J.F., Satcher, J.H., 2006. Atomic layer deposition for the conformal coating of nanoporous materials. J. Nanomater. 2006, 1-5. https://doi.org/10.1155/JNM/2006/64501

Elias, J., Bechelany, M., Utke, I., Erni, R., Hosseini, D., Michler, J., Philippe, L., 2012. Urchin-inspired zinc oxide as building blocks for nanostructured solar cells. Nano Energy 1, 696-705. https://doi.org/10.1016/j.nanoen.2012.07.002

Finch, D.S., Oreskovic, T., Ramadurai, K., Herrmann, C.F., George, S.M., Mahajan, R.L., 2008.

Biocompatibility of atomic layer-deposited alumina thin films. J. Biomed. Mater. Res. - Part A 87, 100-106. https://doi.org/10.1002/jbm.a.31732

Fu, X., Cheng, Z., Yu, J., Choo, P., Chen, L., Choo, J., 2016. A SERS-based lateral flow assay biosensor for highly sensitive detection of HIV-1 DNA. Biosens. Bioelectron. 78, 530-537. https://doi.org/10.1016/J.BIOS.2015.11.099

George, S.M., Steven M. George, 2010. Atomic Layer Deposition: An Overview. Chem. Rev. 110, 111131. https://doi.org/10.1021/cr900056b

Gervais, L., Gel, M., Allain, B., Tolba, M., Brovko, L., Zourob, M., Mandeville, R., Griffiths, M., Evoy, S., 2007. Immobilization of biotinylated bacteriophages on biosensor surfaces. Sensors Actuators, B Chem. 125, 615-621. https://doi.org/10.1016/j.snb.2007.03.007

Gong, Y., Palacio, D., Song, X., Patel, R.L., Liang, X., Zhao, X., Goodenough, J.B., Huang, K., 2013. Stabilizing nanostructured solid oxide fuel cell cathode with atomic layer deposition. Nano Lett. 13, 4340-4345. https://doi.org/10.1021/nl402138w

Green, M.L., Ho, M.-Y., Busch, B., Wilk, G.D., Sorsch, T., Conard, T., Brijs, B., Vandervorst, W., Räisänen, P.I., Muller, D., Bude, M., Grazul, J., 2002. Nucleation and growth of atomic layer 
deposited $\mathrm{HfO}_{2}$ gate dielectric layers on chemical oxide $(\mathrm{Si}-\mathrm{O}-\mathrm{H})$ and thermal oxide $\left(\mathrm{SiO}_{2}\right.$ or $\mathrm{Si}-$ O-N) underlayers. J. Appl. Phys. 92, 7168-7174. https://doi.org/10.1063/1.1522811

Gu, Y.-Z., Lu, H., Geng, Y., Ye, Z.-Y., Zhang, Y., Sun, Q.-Q., Ding, S.-J., Zhang, D.W., 2013. Optical and microstructural properties of $\mathrm{ZnO} / \mathrm{TiO}_{2}$ nanolaminates prepared by atomic layer deposition. Nanoscale Res. Lett. 8, 107. https://doi.org/10.1186/1556-276X-8-107

Guo, D.J., Abdulagatov, A.I., Rourke, D.M., Bertness, K.A., George, S.M., Lee, Y.C., Tan, W., 2010. GaN nanowire functionalized with atomic layer deposition techniques for enhanced immobilization of biomolecules. Langmuir 26, 18382-18391. https://doi.org/10.1021/la103337a

Gusev, E.P., Copel, M., Gribelyuk, M., 2003. Ultrathin $\mathrm{HfO}_{2}$ films grown on silicon by atomic layer deposition for advanced gate dielectrics applications. Microelectron. Eng. 69, 145-151. https://doi.org/10.1016/S0167-9317(03)00291-0

Gutowski, M., Jaffe, J.E., Liu, C.-L., Stoker, M., Hegde, R.I., Rai, R.S., Tobin, P.J., 2002. Thermodynamic stability of high- $K$ dielectric metal oxides $\mathrm{ZrO}_{2}$ and $\mathrm{HfO}_{2}$ in contact with $\mathrm{Si}$ and $\mathrm{SiO}_{2}$. Appl. Phys. Lett. 80, 1897-1899. https://doi.org/10.1063/1.1458692

Hämäläinen, J., Ritala, M., Leskelä, M., 2014. Atomic Layer Deposition of Noble Metals and Their Oxides. Chem. Mater. 26, 786-801. https://doi.org/10.1021/cm402221y

Ho, T.A., Bae, C., Nam, H., Kim, E., Lee, S.Y., Park, J.H., Shin, H., 2018. Metallic Ni 3 S 2 Films Grown by Atomic Layer Deposition as an Efficient and Stable Electrocatalyst for Overall Water Splitting. ACS Appl. Mater. Interfaces 10, 12807-12815. https://doi.org/10.1021/acsami.8b00813

Hoffmann, L., Brinkmann, K.O., Malerczyk, J., Rogalla, D., Becker, T., Theirich, D., Shutsko, I., Görrn, P., Riedl, T., 2018. Spatial Atmospheric Pressure Atomic Layer Deposition of Tin Oxide as an Impermeable Electron Extraction Layer for Perovskite Solar Cells with Enhanced Thermal Stability. ACS Appl. Mater. Interfaces 10, 6006-6013. https://doi.org/10.1021/acsami.7b17701

Hong, K.J., Kim, S.O., 2016. Atomic layer deposition assisted sacrificial template synthesis of mesoporous $\mathrm{TiO}_{2}$ electrode for high performance lithium ion battery anodes. Energy Storage Mater. 2, 27-34. https://doi.org/10.1016/j.ensm.2015.11.002

Hong, Y., Kim, C.H., Shin, J., Kim, K.Y., Kim, J.S., Hwang, C.S., Lee, J.H., 2016. Highly selective ZnO gas sensor based on MOSFET having a horizontal floating-gate. Sensors Actuators, B Chem. 232, 653-659. https://doi.org/10.1016/j.snb.2016.04.010

Hoye, R.L.Z., Muñoz-Rojas, D., Nelson, S.F., Illiberi, A., Poodt, P., Roozeboom, F., MacManus-Driscoll, J.L., 2015. Research Update: Atmospheric pressure spatial atomic layer deposition of $\mathrm{ZnO}$ thin films: Reactors, doping, and devices. APL Mater. 3, 40701. https://doi.org/10.1063/1.4916525

Im, H., Bantz, K.C., Lee, S.H., Johnson, T.W., Haynes, C.L., Oh, S.-H., 2013. Self-Assembled Plasmonic Nanoring Cavity Arrays for SERS and LSPR Biosensing. Adv. Mater. 25, 2678-2685. https://doi.org/10.1002/adma.201204283

Im, H., Wittenberg, N.J., Lindquist, N.C., Oh, S.H., 2012. Atomic layer deposition: A versatile technique for plasmonics and nanobiotechnology. J. Mater. Res. https://doi.org/10.1557/jmr.2011.434

Jakob, M.H., Dong, B., Gutsch, S., Chatelle, C., Krishnaraja, A., Weber, W., Zacharias, M., 2017. Labelfree $\mathrm{SnO}_{2}$ nanowire FET biosensor for protein detection. Nanotechnology 28, 245503. https://doi.org/10.1088/1361-6528/aa7015 
Jang, D.-Y., Kim, Y.-P., Kim, H.-S., Ko Park, S.-H., Choi, S.-Y., Choi, Y.-K., 2007. Sublithographic vertical gold nanogap for label-free electrical detection of protein-ligand binding. J. Vac. Sci. Technol. B Microelectron. Nanom. Struct. 25, 443. https://doi.org/10.1116/1.2713403

Johnson, R.W., Hultqvist, A., Bent, S.F., 2014. A brief review of atomic layer deposition: From fundamentals to applications. Mater. Today 17, 236-246. https://doi.org/10.1016/j.mattod.2014.04.026

Kasianowicz, J.J., Brandin, E., Branton, D., Deamer, D.W., 1996. Characterization of individual polynucleotide molecules using a membrane channel. Proc. Natl. Acad. Sci. 93, 13770-13773. https://doi.org/10.1073/pnas.93.24.13770

Kim, B.-Y., Sohn, I., Lee, D., Han, G.S., Lee, W.-I., Jung, H.S., Lee, N.-E., 2015. Ultrarapid and ultrasensitive electrical detection of proteins in a three-dimensional biosensor with high capture efficiency. Nanoscale 7, 9844-9851. https://doi.org/10.1039/C5NR00909J

Kim, H., 2003. Atomic layer deposition of metal and nitride thin films: Current research efforts and applications for semiconductor device processing. J. Vac. Sci. Technol. B Microelectron. Nanom. Struct. 21, 2231. https://doi.org/10.1116/1.1622676

Kim, H., Lee, H.B.R., Maeng, W.J., 2009. Applications of atomic layer deposition to nanofabrication and emerging nanodevices. Thin Solid Films 517, 2563-2580. https://doi.org/10.1016/j.tsf.2008.09.007

Kim, J.Y., Jo, S.-Y., Sun, G.-J., Katoch, A., Choi, S.-W., Kim, S.S., 2014. Tailoring the surface area of ZnO nanorods for improved performance in glucose sensors. Sensors Actuators B Chem. 192, 216-220. https://doi.org/10.1016/j.snb.2013.10.113

Kim, Y.W., Sardari, S.E., Meyer, M.T., Iliadis, A.A., Wu, H.C., Bentley, W.E., Ghodssi, R., 2012. An ALD aluminum oxide passivated Surface Acoustic Wave sensor for early biofilm detection. Sensors Actuators, B Chem. 163, 136-145. https://doi.org/10.1016/j.snb.2012.01.021

Knez, M., Nielsch, K., Niinistö, L., 2007. Synthesis and surface engineering of complex nanostructures by atomic layer deposition. Adv. Mater. 19, 3425-3438. https://doi.org/10.1002/adma.200700079

Krishna, V.D., Wu, K., Perez, A.M., Wang, J.-P., 2016. Giant Magnetoresistance-based Biosensor for Detection of Influenza A Virus. Front. Microbiol. 7, 400. https://doi.org/10.3389/fmicb.2016.00400

Kukli, K., Ritala, M., Aarik, J., Uustare, T., Leskelä, M., 2002. Influence of growth temperature on properties of zirconium dioxide films grown by atomic layer deposition. J. Appl. Phys. 92, 18331840. https://doi.org/10.1063/1.1493657

Lee, M., Zine, N., Baraket, A., Zabala, M., Campabadal, F., Caruso, R., Trivella, M.G., Jaffrezic-Renault, N., Errachid, A., 2012. A novel biosensor based on hafnium oxide: Application for early stage detection of human interleukin-10. Sensors Actuators, B Chem. 175, 201-207. https://doi.org/10.1016/j.snb.2012.04.090

Lee, W.-I., Shrivastava, S., Duy, L.-T., Yeong Kim, B., Son, Y.-M., Lee, N.-E., 2017. A smartphone imaging-based label-free and dual-wavelength fluorescent biosensor with high sensitivity and accuracy. Biosens. Bioelectron. 94, 643-650. https://doi.org/10.1016/j.bios.2017.03.061

Lepoitevin, M., Bechelany, M., Balanzat, E., Janot, J.M., Balme, S., 2016. Non-Fluorescence label protein sensing with track-etched nanopore decorated by avidin/biotin system. Electrochim. Acta 211, 611-618. https://doi.org/10.1016/j.electacta.2016.06.079 
Lepoitevin, M., Ma, T., Bechelany, M., Janot, J.-M., Balme, S., 2017. Functionalization of single solid state nanopores to mimic biological ion channels: A review. Adv. Colloid Interface Sci. 250, 195213. https://doi.org/10.1016/j.cis.2017.09.001

Lepoitevin, M., Nguyen, G., Bechelany, M., Balanzat, E., Janot, J.M., Balme, S., 2015. Combining a sensor and a pH-gated nanopore based on an avidin-biotin system. Chem. Commun. 51, 59945997. https://doi.org/10.1039/c4cc10087e

Leskelä, M., Ritala, M., 2003. Atomic Layer Deposition Chemistry: Recent Developments and Future Challenges. Angew. Chemie Int. Ed. 42, 5548-5554. https://doi.org/10.1002/anie.200301652

Leskelä, M., Ritala, M., 2002. Atomic layer deposition (ALD): From precursors to thin film structures, in: Thin Solid Films. Elsevier, pp. 138-146. https://doi.org/10.1016/S0040-6090(02)00117-7

Li, Q., Lu, N., Wang, L., Fan, C., 2018. Advances in Nanowire Transistor-Based Biosensors. Small Methods 2, 1700263. https://doi.org/10.1002/smtd.201700263

Li, X., Puttaswamy, M., Wang, Z., Kei Tan, C., Grimsdale, A.C., Kherani, N.P., Tok, A.I.Y., 2017. A pressure tuned stop-flow atomic layer deposition process for $\mathrm{MoS}_{2}$ on high porous nanostructure and fabrication of $\mathrm{TiO}_{2} / \mathrm{MoS}_{2}$ core/shell inverse opal structure. Appl. Surf. Sci. 422, 536-543. https://doi.org/10.1016/j.apsusc.2017.06.016

Lichtenstein, A., Havivi, E., Shacham, R., Hahamy, E., Leibovich, R., Pevzner, A., Krivitsky, V., Davivi, G., Presman, I., Elnathan, R., Engel, Y., Flaxer, E., Patolsky, F., 2014. Supersensitive fingerprinting of explosives by chemically modified nanosensors arrays. Nat. Commun. 5, 4195. https://doi.org/10.1038/ncomms5195

Lim, B.S., Rahtu, A., Gordon, R.G., 2003. Atomic layer deposition of transition metals. Nat. Mater. 2, 749-754. https://doi.org/10.1038/nmat1000

Liu, J., Banis, M.N., Sun, Q., Lushington, A., Li, R., Sham, T.K., Sun, X., 2014. Rational Design of Atomic-Layer-Deposited $\mathrm{LiFePO}_{4}$ as a High-Performance Cathode for Lithium-Ion Batteries. Adv. Mater. 26, 6472-6477. https://doi.org/10.1002/adma.201401805

Liu, S., Tong, Z., Mu, X., Liu, B., Du, B., Liu, Z., Gao, C., 2018. Detection of Abrin by Electrochemiluminescence Biosensor Based on Screen Printed Electrode. Sensors 18, 357. https://doi.org/10.3390/s18020357

Longrie, D., Deduytsche, D., Haemers, J., Smet, P.F., Driesen, K., Detavernier, C., 2014. Thermal and Plasma-Enhanced Atomic Layer Deposition of TiN Using TDMAT and $\mathrm{NH}_{3}$ on Particles Agitated in a Rotary Reactor. ACS Appl. Mater. Interfaces 6, 7316-7324. https://doi.org/10.1021/am5007222

Luo, J., Liu, X., Tian, Q., Yue, W., Zeng, J., Chen, G., Cai, X., 2009. Disposable bioluminescence-based biosensor for detection of bacterial count in food. Anal. Biochem. 394, 1-6. https://doi.org/10.1016/j.ab.2009.05.021

Malygin, A.A., Drozd, V.E., Malkov, A.A., Smirnov, V.M., 2015. From V. B. Aleskovskii's "Framework" Hypothesis to the Method of Molecular Layering/Atomic Layer Deposition. Chem. Vap. Depos. 21, 216-240. https://doi.org/10.1002/cvde.201502013

Marichy, C., Bechelany, M., Pinna, N., 2012. Atomic layer deposition of nanostructured materials for energy and environmental applications. Adv. Mater. 24, 1017-1032. https://doi.org/10.1002/adma.201104129 
Matero, R., Ritala, M., Leskelä, M., Salo, T., Aromaa, J., Forsén, O., 1999. Atomic layer deposited thin films for corrosion protection. Le J. Phys. IV 9, Pr8-493-Pr8-499.

https://doi.org/10.1051/jp4:1999862

Maydannik, P.S., Kääriäinen, T.O., Lahtinen, K., Cameron, D.C., Söderlund, M., Soininen, P., Johansson, P., Kuusipalo, J., Moro, L., Zeng, X., 2014. Roll-to-roll atomic layer deposition process for flexible electronics encapsulation applications. J. Vac. Sci. Technol. A Vacuum, Surfaces, Film. 32, 51603. https://doi.org/10.1116/1.4893428

Meng, X., Cao, Y., Libera, J.A., Elam, J.W., 2017. Atomic Layer Deposition of Aluminum Sulfide: Growth Mechanism and Electrochemical Evaluation in Lithium-Ion Batteries. Chem. Mater. 29, 9043-9052. https://doi.org/10.1021/acs.chemmater.7b02175

Miles, B.N., Ivanov, A.P., Wilson, K.A., Doğan, F., Japrung, D., Edel, J.B., 2013. Single molecule sensing with solid-state nanopores: Novel materials, methods, and applications. Chem. Soc. Rev. https://doi.org/10.1039/c2cs35286a

Mishra, A., Kumar, J., Melo, J.S., 2017. An optical microplate biosensor for the detection of methyl parathion pesticide using a biohybrid of Sphingomonas sp. cells-silica nanoparticles. Biosens. Bioelectron. 87, 332-338. https://doi.org/10.1016/J.BIOS.2016.08.048

Muhammad-Tahir, Z., Alocilja, E.C., 2003. A conductometric biosensor for biosecurity. Biosens. Bioelectron. 18, 813-819. https://doi.org/10.1016/S0956-5663(03)00020-4

Muñoz-Rojas, D., MacManus-Driscoll, J., 2014. Spatial atmospheric atomic layer deposition: a new laboratory and industrial tool for low-cost photovoltaics. Mater. Horiz. 1, 314-320. https://doi.org/10.1039/C3MH00136A

Nakashima, Y., Ohno, Y., Kishimoto, S., Okochi, M., Honda, H., Mizutani, T., 2010. Fabrication Process of Carbon Nanotube Field Effect Transistors Using Atomic Layer Deposition Passivation for Biosensors. J. Nanosci. Nanotechnol. 10, 3805-3809. https://doi.org/10.1166/jnn.2010.1983

Nam, H., Oh, B.-R., Chen, P., Yoon, J.S., Wi, S., Chen, M., Kurabayashi, K., Liang, X., 2015. Two different device physics principles for operating MoS 2 transistor biosensors with femtomolarlevel detection limits. Appl. Phys. Lett. 107, 12105. https://doi.org/10.1063/1.4926800

Nam, W.H., Rhee, S.W., 2004. Atomic layer deposition of $\mathrm{ZrO}_{2}$ thin films using dichlorobis[bis(trimethylsilyl)amido]zirconium and water. Chem. Vap. Depos. 10, 201-205. https://doi.org/10.1002/cvde.200306277

Niinistö, L., Päiväsaari, J., Niinistö, J., Putkonen, M., Nieminen, M., 2004. Advanced electronic and optoelectronic materials by atomic layer deposition: An overview with special emphasis on recent progress in processing of high-k dielectrics and other oxide materials. Phys. Status Solidi Appl. Res. https://doi.org/10.1002/pssa.200406798

O’Neill, B.J., Jackson, D.H.K., Lee, J., Canlas, C., Stair, P.C., Marshall, C.L., Elam, J.W., Kuech, T.F., Dumesic, J.A., Huber, G.W., 2015. Catalyst Design with Atomic Layer Deposition. ACS Catal. 5, 1804-1825. https://doi.org/10.1021/cs501862h

Oubaha, M., Gorin, A., McDonagh, C., Duffy, B., Copperwhite, R., 2015. Development of a multianalyte optical sol-gel biosensor for medical diagnostic. Sensors Actuators B Chem. 221, 96-103. https://doi.org/10.1016/j.snb.2015.06.012

Pessoa, R.S., dos Santos, V.P., Cardoso, S.B., Doria, A.C.O.C., Figueira, F.R., Rodrigues, B.V.M., Testoni, G.E., Fraga, M.A., Marciano, F.R., Lobo, A.O., Maciel, H.S., 2017. $\mathrm{TiO}_{2}$ coatings via 
atomic layer deposition on polyurethane and polydimethylsiloxane substrates: Properties and effects on C. albicans growth and inactivation process. Appl. Surf. Sci. 422, 73-84.

https://doi.org/10.1016/j.apsusc.2017.05.254

Peters, A.W., Li, Z., Farha, O.K., Hupp, J.T., 2015. Atomically Precise Growth of Catalytically Active Cobalt Sulfide on Flat Surfaces and within a Metal-Organic Framework via Atomic Layer Deposition. ACS Nano 9, 8484-8490. https://doi.org/10.1021/acsnano.5b03429

Poinern, G.E.J., Ali, N., Fawcett, D., 2011. Progress in Nano-Engineered Anodic Aluminum Oxide Membrane Development. Materials 4, 487-526. https://doi.org/10.3390/ma4030487

Ponraj, J.S., Attolini, G., Bosi, M., 2013. Review on Atomic Layer Deposition and Applications of Oxide Thin Films. Crit. Rev. Solid State Mater. Sci. 38, 203-233. https://doi.org/10.1080/10408436.2012.736886

Poodt, P., Cameron, D.C., Dickey, E., George, S.M., Kuznetsov, V., Parsons, G.N., Roozeboom, F., Sundaram, G., Vermeer, A., 2012. Spatial atomic layer deposition: A route towards further industrialization of atomic layer deposition. J. Vac. Sci. Technol. A Vacuum, Surfaces, Film. 30, 10802. https://doi.org/10.1116/1.3670745

Puurunen, R.L., 2014. A short history of atomic layer deposition: Tuomo Suntola's atomic layer epitaxy. Chem. Vap. Depos. 20, 332-344. https://doi.org/10.1002/cvde.201402012

Rissanen, A., Kantojärvi, U., Blomberg, M., Antila, J., Eränen, S., 2012. Monolithically integrated microspectrometer-on-chip based on tunable visible light MEMS FPI. Sensors Actuators A Phys. 182, 130-135. https://doi.org/10.1016/j.sna.2012.05.023

Ritala, M., Leskelä, M., 2002. Atomic layer deposition, in: Handbook of Thin Films. Elsevier, pp. 103159. https://doi.org/10.1016/B978-012512908-4/50005-9

Ronkainen, N.J., Halsall, H.B., Heineman, W.R., 2010. Electrochemical biosensors. Chem. Soc. Rev. 39, 1747-1763. https://doi.org/10.1039/b714449k

Sarkar, D., Liu, W., Xie, X., Anselmo, A.C., Mitragotri, S., Banerjee, K., 2014. MoS2 Field-Effect Transistor for Next-Generation Label-Free Biosensors. ACS Nano 8, 3992-4003. https://doi.org/10.1021/nn5009148

Schindler, M., Kim, S.K., Hwang, C.S., Schindler, C., Offenhäusser, A., Ingebrandt, S., 2008. Novel post-process for the passivation of a CMOS biosensor. Phys. status solidi - Rapid Res. Lett. 2, 46. https://doi.org/10.1002/pssr.200701242

Shan, C.X., Hou, X., Choy, K.L., 2008. Corrosion resistance of $\mathrm{TiO}_{2}$ films grown on stainless steel by atomic layer deposition. Surf. Coatings Technol. 202, 2399-2402. https://doi.org/10.1016/j.surfcoat.2007.08.066

Sharma, K., Hall, R.A., George, S.M., 2015. Spatial atomic layer deposition on flexible substrates using a modular rotating cylinder reactor. J. Vac. Sci. Technol. A Vacuum, Surfaces, Film. 33, 01A132. https://doi.org/10.1116/1.4902086

Smietana, M., Koba, M., Brzozowska, E., Krogulski, K., Nakonieczny, J., Wachnicki, L., Mikulic, P., Godlewski, M., Bock, W.J., 2015. Label-free sensitivity of long-period gratings enhanced by atomic layer deposited $\mathrm{TiO}_{2}$ nano-overlays. Opt. Express 23, 8441. https://doi.org/10.1364/OE.23.008441

Sobel, N., Hess, C., 2015. Nanoscale Structuring of Surfaces by Using Atomic Layer Deposition. 
Angew. Chemie Int. Ed. 54, 15014-15021. https://doi.org/10.1002/anie.201503680

Spende, A., Sobel, N., Lukas, M., Zierold, R., Riedl, J.C., Gura, L., Schubert, I., Moreno, J.M.M., Nielsch, K., Stühn, B., Hess, C., Trautmann, C., Toimil-Molares, M.E., 2015. $\mathrm{TiO}_{2}$, $\mathrm{SiO}_{2}$, and $\mathrm{Al}_{2} \mathrm{O}_{3}$ coated nanopores and nanotubes produced by ALD in etched ion-track membranes for transport measurements. Nanotechnology 26, 335301. https://doi.org/10.1088/0957$4484 / 26 / 33 / 335301$

Standridge, S.D., Schatz, G.C., Hupp, J.T., 2009. Toward plasmonic solar cells: Protection of silver nanoparticles via atomic layer deposition of $\mathrm{TiO}_{2}$. Langmuir 25, 2596-2600.

https://doi.org/10.1021/la900113e

Sticker, D., Rothbauer, M., Charwat, V., Steinkühler, J., Bethge, O., Bertagnolli, E., Wanzenboeck, H.D., Ertl, P., 2015. Zirconium dioxide nanolayer passivated impedimetric sensors for cell-based assays. Sensors Actuators, B Chem. 213, 35-44. https://doi.org/10.1016/j.snb.2015.02.018

Sun, S., Zhang, G., Gauquelin, N., Chen, N., Zhou, J., Yang, S., Chen, W., Meng, X., Geng, D., Banis, M.N., Li, R., Ye, S., Knights, S., Botton, G.A., Sham, T.K., Sun, X., 2013. Single-atom catalysis using Pt/graphene achieved through atomic layer deposition. Sci. Rep. 3, 1775. https://doi.org/10.1038/srep01775

Suntola, T., Antson, J., 1977. Method for producing compound thin films. US Pat. 4,058,430.

Tarish, S., Xu, Y., Wang, Z., Mate, F., Al-Haddad, A., Wang, W., Lei, Y., 2017. Highly efficient biosensors by using well-ordered $\mathrm{ZnO} / \mathrm{ZnS}$ core/shell nanotube arrays. Nanotechnology 28, 405501. https://doi.org/10.1088/1361-6528/aa82b0

Tereshchenko, A., Bechelany, M., Viter, R., Khranovskyy, V., Smyntyna, V., Starodub, N., Yakimova, R., 2016. Optical biosensors based on $\mathrm{ZnO}$ nanostructures: Advantages and perspectives. A review. Sensors Actuators, B Chem. 229, 664-677. https://doi.org/10.1016/j.snb.2016.01.099

Tereshchenko, A., Fedorenko, V., Smyntyna, V., Konup, I., Konup, A., Eriksson, M., Yakimova, R., Ramanavicius, A., Balme, S., Bechelany, M., 2017. ZnO films formed by atomic layer deposition as an optical biosensor platform for the detection of Grapevine virus A-type proteins. Biosens. Bioelectron. 92, 763-769. https://doi.org/10.1016/j.bios.2016.09.071

Thangaraj, V., Lepoitevin, M., Smietana, M., Balanzat, E., Bechelany, M., Janot, J.M., Vasseur, J.J., Subramanian, S., Balme, S., 2016. Detection of short ssDNA and dsDNA by current-voltage measurements using conical nanopores coated with $\mathrm{Al}_{2} \mathrm{O}_{3}$ by atomic layer deposition. Microchim. Acta 183, 1011-1017. https://doi.org/10.1007/s00604-015-1706-2

Turner, A.P.F., 2013. Biosensors: sense and sensibility. Chem. Soc. Rev. 42, 3184. https://doi.org/10.1039/c3cs35528d

Vähä-Nissi, M., Pitkänen, M., Salo, E., Kenttä, E., Tanskanen, A., Sajavaara, T., Putkonen, M., Sievänen, J., Sneck, A., Rättö, M., Karppinen, M., Harlin, A., 2014. Antibacterial and barrier properties of oriented polymer films with $\mathrm{ZnO}$ thin films applied with atomic layer deposition at low temperatures. Thin Solid Films 562, 331-337. https://doi.org/10.1016/j.tsf.2014.03.068

Van Delft, J.A., Garcia-Alonso, D., Kessels, W.M.M., 2012. Atomic layer deposition for photovoltaics: Applications and prospects for solar cell manufacturing. Semicond. Sci. Technol. 27. https://doi.org/10.1088/0268-1242/27/7/074002

Velasco-Garcia, M.N., Mottram, T., 2003. Biosensor Technology addressing Agricultural Problems. Biosyst. Eng. 84, 1-12. https://doi.org/10.1016/S1537-5110(02)00236-2 
Vello, T.P., da Silva, L.M.B., Silva, G.O., de Camargo, D.H.S., Corrêa, C.C., Bof Bufon, C.C., 2017. Hybrid organic/inorganic interfaces as reversible label-free platform for direct monitoring of biochemical interactions. Biosens. Bioelectron. 87, 209-215. https://doi.org/10.1016/j.bios.2016.08.050

Viter, R., Chaaya, A.A., Iatsunskyi, I., Nowaczyk, G., Kovalevskis, K., Erts, D., Miele, P., Smyntyna, V., Bechelany, M., 2015. Tuning of ZnO 1D nanostructures by atomic layer deposition and electrospinning for optical gas sensor applications. Nanotechnology 26, 105501. https://doi.org/10.1088/0957-4484/26/10/105501

Wang, G., Gao, Z., Tang, S., Chen, C., Duan, F., Zhao, S., Lin, S., Feng, Y., Zhou, L., Qin, Y., 2012. Microwave absorption properties of carbon nanocoils coated with highly controlled magnetic materials by atomic layer deposition. ACS Nano 6, 11009-11017. https://doi.org/10.1021/nn304630h

Wang, L., Wang, Y., Wong, J.I., Palacios, T., Kong, J., Yang, H.Y., 2014. Functionalized MoS2 Nanosheet-Based Field-Effect Biosensor for Label-Free Sensitive Detection of Cancer Marker Proteins in Solution. Small 10, 1101-1105. https://doi.org/10.1002/smll.201302081

Weber, M., Iatsunskyi, I., Coy, E., Miele, P., Cornu, D., Bechelany, M., 2018. Novel and Facile Route for the Synthesis of Tunable Boron Nitride Nanotubes Combining Atomic Layer Deposition and Annealing Processes for Water Purification. Adv. Mater. Interfaces 5, 1800056. https://doi.org/10.1002/admi.201800056

Weber, M., Koonkaew, B., Balme, S., Utke, I., Picaud, F., Iatsunskyi, I., Coy, E., Miele, P., Bechelany, M., 2017. Boron Nitride Nanoporous Membranes with High Surface Charge by Atomic Layer Deposition. ACS Appl. Mater. Interfaces 9, 16669-16678. https://doi.org/10.1021/acsami.7b02883

Weber, M.J., MacKus, A.J.M., Verheijen, M.A., Longo, V., Bol, A.A., Kessels, W.M.M., 2014. Atomic layer deposition of high-purity palladium films from $\mathrm{Pd}(\mathrm{hfac})_{2}$ and $\mathrm{H}_{2}$ and $\mathrm{O}_{2}$ plasmas. J. Phys. Chem. C 118, 8702-8711. https://doi.org/10.1021/jp5009412

Weber, M.J., Mackus, A.J.M., Verheijen, M.A., van der Marel, C., Kessels, W.M.M., 2012. Supported Core/Shell Bimetallic Nanoparticles Synthesis by Atomic Layer Deposition. Chem. Mater. 24, 2973-2977. https://doi.org/10.1021/cm301206e

Weber, M.J., Verheijen, M.A., Bol, A.A., Kessels, W.M.M., 2015. Sub-nanometer dimensions control of core/shell nanoparticles prepared by atomic layer deposition. Nanotechnology 26, 94002. https://doi.org/10.1088/0957-4484/26/9/094002

Xiong, S., Kong, L., Huang, J., Chen, X., Wang, Y., 2015. Atomic-layer-deposition-enabled nonwoven membranes with hierarchical $\mathrm{ZnO}$ nanostructures for switchable water/oil separations. J. Memb. Sci. 493, 478-485. https://doi.org/10.1016/j.memsci.2015.06.054

Yang, P., Tong, X., Wang, G., Gao, Z., Guo, X., Qin, Y., 2015. NiO/SiC nanocomposite prepared by atomic layer deposition used as a novel electrocatalyst for nonenzy matic glucose sensing. ACS Appl. Mater. Interfaces 7, 4772-4777. https://doi.org/10.1021/am508508m

Yao, Z., Wang, C., Li, Y., Kim, N.-Y., 2015. AAO-assisted synthesis of highly ordered, large-scale $\mathrm{TiO}_{2}$ nanowire arrays via sputtering and atomic layer deposition. Nanoscale Res. Lett. 10, 166. https://doi.org/10.1186/s11671-015-0872-9

Ye, P.D., Wilk, G.D., Yang, B., Kwo, J., Chu, S.N.G., Nakahara, S., Gossmann, H.-J.L., Mannaerts, J.P., Hong, M., Ng, K.K., Bude, J., 2003. GaAs metal-oxide-semiconductor field-effect transistor with nanometer-thin dielectric grown by atomic layer deposition. Appl. Phys. Lett. 83, 180-182. 
https://doi.org/10.1063/1.1590743

Yoo, G., Park, H., Kim, M., Song, W.G., Jeong, S., Kim, M.H., Lee, H., Lee, S.W., Hong, Y.K., Lee, M.G., Lee, S., Kim, S., 2017. Real-time electrical detection of epidermal skin MoS2 biosensor for pointof-care diagnostics. Nano Res. 10, 767-775. https://doi.org/10.1007/s12274-016-1289-1

Zafar, S., D’Emic, C., Jagtiani, A., Kratschmer, E., Miao, X., Zhu, Y., Mo, R., Sosa, N., Hamann, H., Shahidi, G., Riel, H., 2018. Silicon Nanowire Field Effect Transistor Sensors with Minimal Sensorto-Sensor Variations and Enhanced Sensing Characteristics. ACS Nano 12, 6577-6587. https://doi.org/10.1021/acsnano.8b01339

Zhang, C., Huang, B., Qian, L., Yuan, S., Wang, S., Chen, R., 2016. Electrochemical Biosensor Based on Nanoporous Au/CoO Core-Shell Material with Synergistic Catalysis. ChemPhysChem 17, $98-$ 104. https://doi.org/10.1002/cphc.201500854

Zhang, K., Zhu, Y., Liu, X., Cui, Z., Xianjin, Y., Yeung, K.W.K., Pan, H., Wu, S., 2017. Sr/ZnO doped titania nanotube array: An effective surface system with excellent osteoinductivity and selfantibacterial activity. Mater. Des. 130, 403-412. https://doi.org/10.1016/j.matdes.2017.05.085

Zhang, S., Geryak, R., Geldmeier, J., Kim, S., Tsukruk, V. V., 2017. Synthesis, Assembly, and Applications of Hybrid Nanostructures for Biosensing. Chem. Rev. 117, 12942-13038. https://doi.org/10.1021/acs.chemrev.7b00088

Zhang, S., Wright, G., Yang, Y., 2000. Materials and techniques for electrochemical biosensor design and construction. Biosens. Bioelectron. 15, 273-282. https://doi.org/10.1016/S0956-5663(00)00076-2

Zhang, X., Zhao, J., Whitney, A. V., Elam, J.W., Van Duyne, R.P., 2006. Ultrastable Substrates for Surface-Enhanced Raman Spectroscopy: $\mathrm{Al}_{2} \mathrm{O}_{3}$ Overlayers Fabricated by Atomic Layer Deposition Yield Improved Anthrax Biomarker Detection. J. Am. Chem. Soc. 128, 10304-10309. https://doi.org/10.1021/ja0638760

Zhao, Y., Pang, F., Dong, Y., Wen, J., Chen, Z., Wang, T., 2013. Refractive index sensitivity enhancement of optical fiber cladding mode by depositing nanofilm via ALD technology. Opt. Express 21, 26136. https://doi.org/10.1364/OE.21.026136

Zhao, Y., Zhou, C., Zhang, X., Zhang, P., Dou, Y., Wang, W., Cao, X., Wang, B., Tang, Y., Zhou, S., 2013. Passivation mechanism of thermal atomic layer-deposited $\mathrm{Al}_{2} \mathrm{O}_{3}$ films on silicon at different annealing temperatures. Nanoscale Res. Lett. 8, 114. https://doi.org/10.1186/1556-276X-8-114

Zhu, S., Pang, F., Huang, S., Zou, F., Guo, Q., Wen, J., Wang, T., 2016. High sensitivity refractometer based on $\mathrm{TiO}_{2}$-Coated adiabatic tapered optical fiber via ALD technology. Sensors 16, 1295. https://doi.org/10.3390/s16081295 